
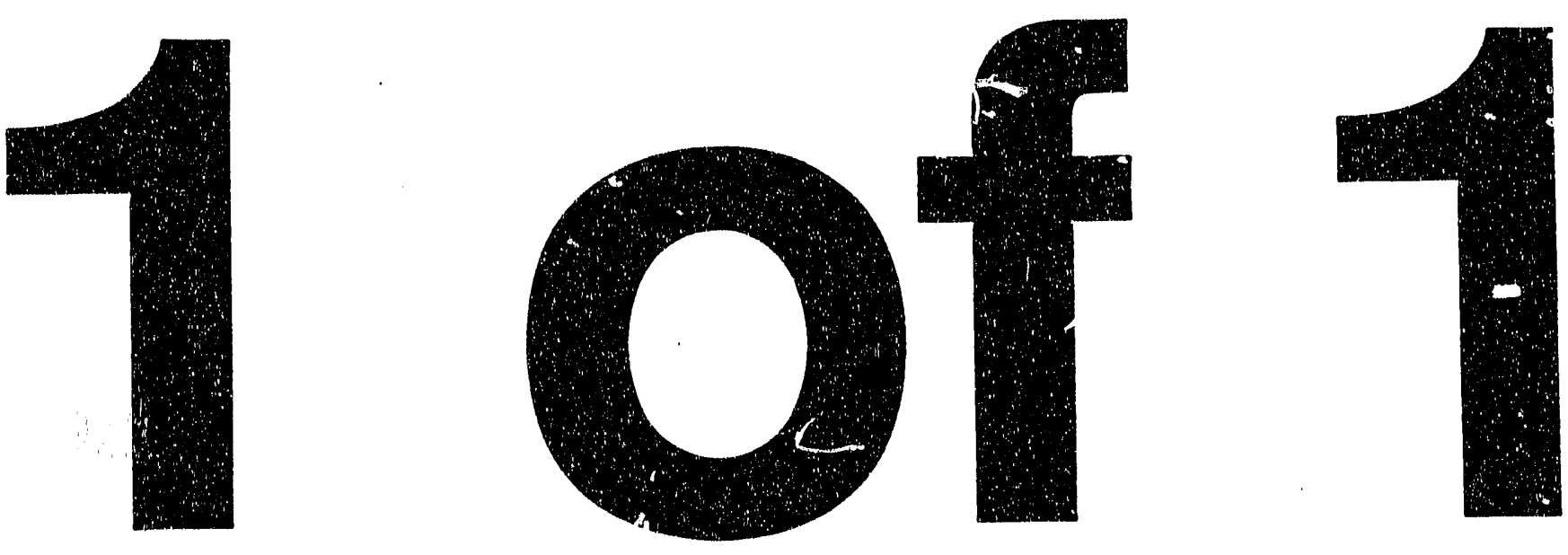
ONSITE (cont.)
E. H. Neilsen
A. D. Olguin
J. W. Osborne
P. Sathyanarayana (2)
R. D. Schreiber (2)
C. L. Thomas
T. C. Trible
R. S. Viswanath
M. D. Webb
R. Westberg
Central Files
O.S.T.I. (2)

$\begin{array}{ll}\text { S7-12 } & X \\ \text { S7-04 } & X \\ \text { S7-15 } & X \\ \text { R2-12 } & X \\ \text { R2-12 } & X \\ H 4-19 & X \\ \text { S1-57 } & X \\ \text { S3-90 } & X \\ \text { H4 }-25 & X \\ \text { S3-90 } & X \\ \text { L8-04 } & X \\ \text { L8-07 } & X\end{array}$

\section{OFFSITE}

U.S. Department of Energy - Headquarters

Office of Environmental Restoration

and Waste Management EM-563

12800 Middlebrook Road

Germantown, MD 20874

K. T. Lang

J. A. Poppitti

$\underset{x}{x}$

$X$

Oak Ridge National Laboratory

Post Office Box 2008

0 kk Ridge, TN 37831-6120

k. A. Jenkins

A. D. Dindal

$\underset{x}{x}$

Los Alamos Techrical Associates

750 Swift, Suite 14

Richland, WA 99352
A. T. Dicenso
C. J. Lindquist
G. P. Westleigh
T. T. Tran 


\begin{tabular}{|c|c|c|c|c|c|}
\hline \multicolumn{6}{|c|}{ DISTRIBUTION SHEET } \\
\hline \multirow{2}{*}{$\begin{array}{l}\text { To } \\
\text { Distribution }\end{array}$} & \multirow{2}{*}{\multicolumn{3}{|c|}{$\begin{array}{l}\text { From } \\
\text { Characterization Support }\end{array}$}} & \multicolumn{2}{|l|}{ Page 1 of 2} \\
\hline & & & & \multicolumn{2}{|c|}{ Date 03-16-95 } \\
\hline \multirow{2}{*}{\multicolumn{4}{|c|}{$\begin{array}{l}\text { Project Title/Work Order } \\
\text { Tank 241-TY-101 Tank Characterization Plan (WHC-SD-WM-TP-299) }\end{array}$}} & \multicolumn{2}{|c|}{ EDT No. 610022} \\
\hline & & & & \multicolumn{2}{|l|}{ ECN No. } \\
\hline Name & MSIN & $\begin{array}{c}\text { Text } \\
\text { With All } \\
\text { Attach. }\end{array}$ & Text Only & $\begin{array}{l}\text { Attach./ } \\
\text { Appendix } \\
\text { Only }\end{array}$ & $\begin{array}{l}\text { EDT/ECN } \\
\text { Only }\end{array}$ \\
\hline
\end{tabular}

\section{ONSITE}

\section{DOE-RL}
C. A. Babel
J. M. Clark
W. Liou
J. F. Thompson
N. W. Will is

\section{MACTEC}

$\begin{array}{ll}\text { S7-54 } & x \\ 57-54 & x \\ 57-54 & x \\ 57-54 & X \\ \text { S7-54 } & X\end{array}$

P7-14

P8-08

K6-96

P8-08

P7-59

P7-27

$x$
$\hat{x}$

$57-73$

B1-42

G7-56

R3-01

S7-15

R2-12

S3-90

57-31

S1-57

S7-04

H4-19

R2-12

S5-03

T6-06

G7-56

S3-90

S7-15

H4-19

$$
\begin{aligned}
& x \\
& x \\
& x \\
& x \\
& x \\
& x
\end{aligned}
$$

J. P. Haney

D. R. Lincoln

J. A. Sheriff

\section{Pacific Northwest Laboratories}

B. 0. Barnes

J. A. Edwards

J. S. Fruchter

S. C. Goheen

M. W. Ligotke

K. L. Silvers

Westinghouse Hanford Company

C. H. Brevick

D. R. Carls

R. J. Cash

S. J. Eberlein

D. L. Edwards

G. D. Forehand

H. Y. Fouad

D. J. Green

V. W. Hall

C. S. Homi

W. J. Kennedy

J. G. Kristofzski

T. J. Kunthara

R. D. Mahon

J. E. Meacham

P. M. Morant 


\section{To: (Receiving Organization? SAMPLING AND MOBILE LABORATORIES}

5. Proj./Prog./Dept./Div.: TWRS ENG/CHAR SUPPORT 8. Originator Remarks: N/A
3. From: (originating organization) TWRS/CHARACTERIZATION SUPPORT

6. Cog. Engr.:

C. S. HOMI
4. Related EDT NO.:

$N / A$

7. Purchase Order No.: $N / A$

9. Equip./Component No.: $N / A$

10. System/Bldg./Facility: 2750E/200E

11. Receiver Renarks: $N / A$

12. Major Assm. Dwg. No.:

13. Permit/Permit Application No.: $N / A$

14. Required Response Date: $03 / 16 / 95$

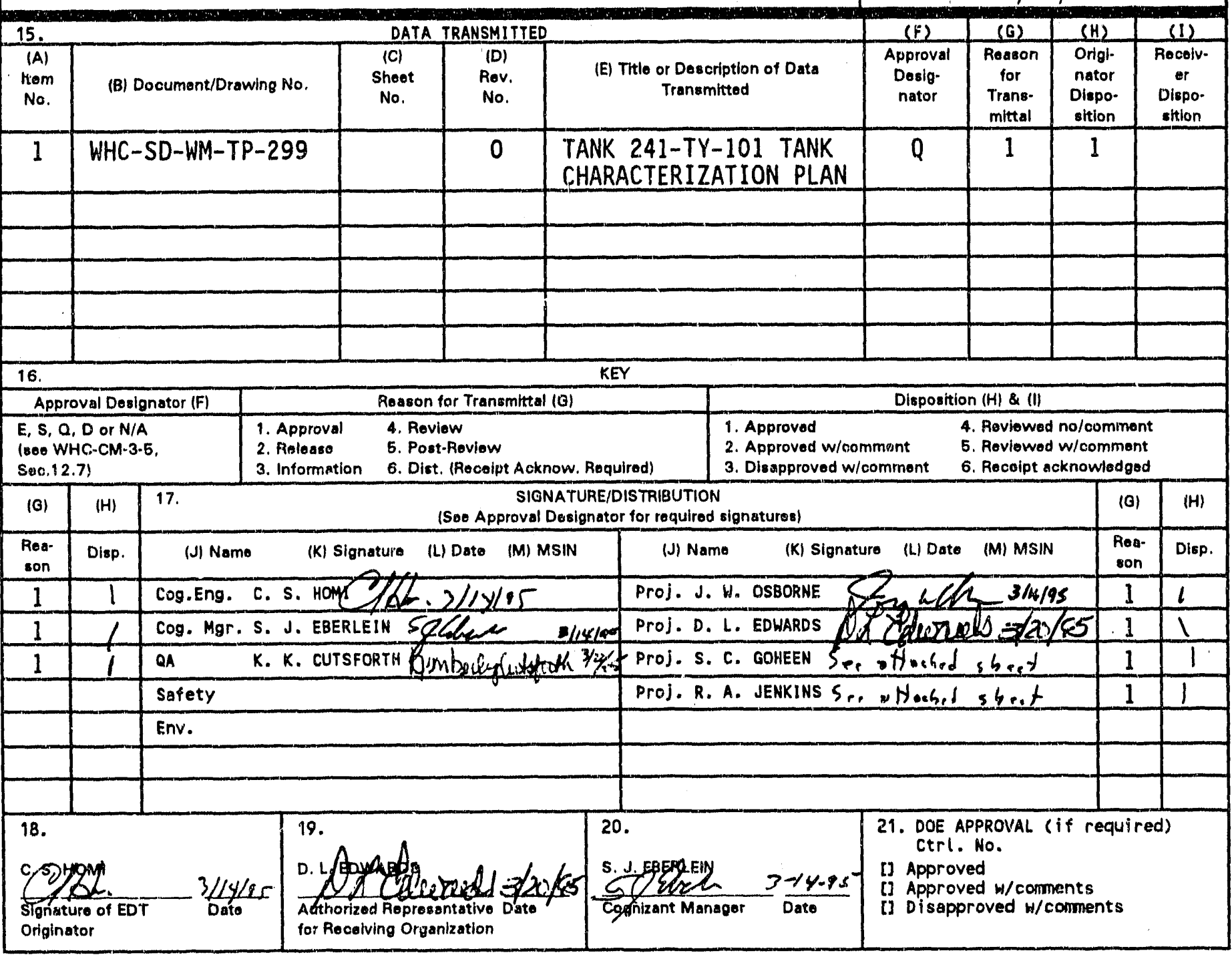




\section{ENGINEERINO DATA TRANISMITTAL}

1. 610022

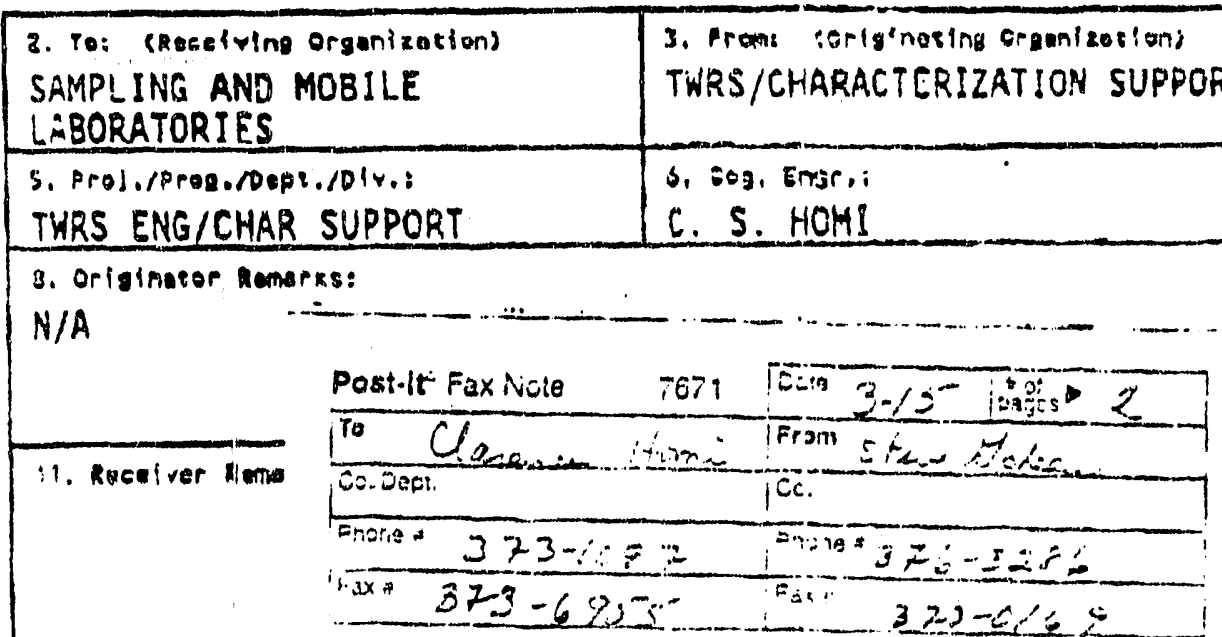

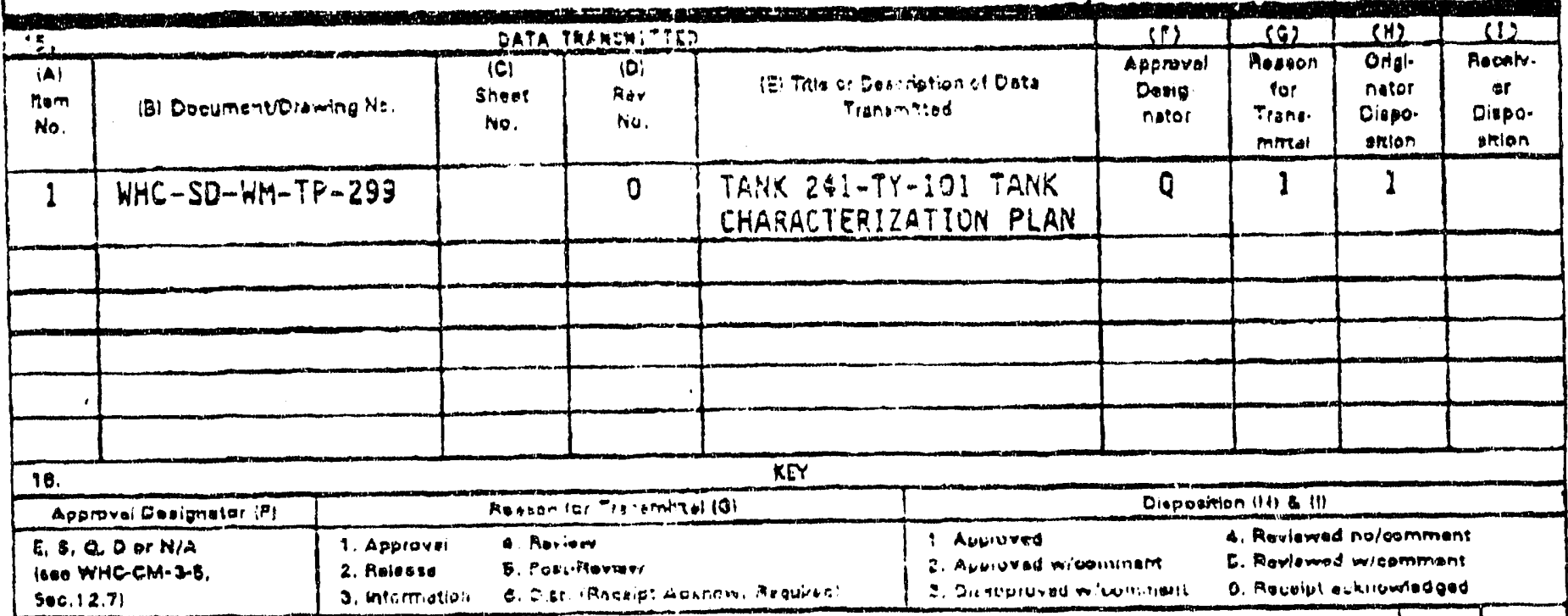

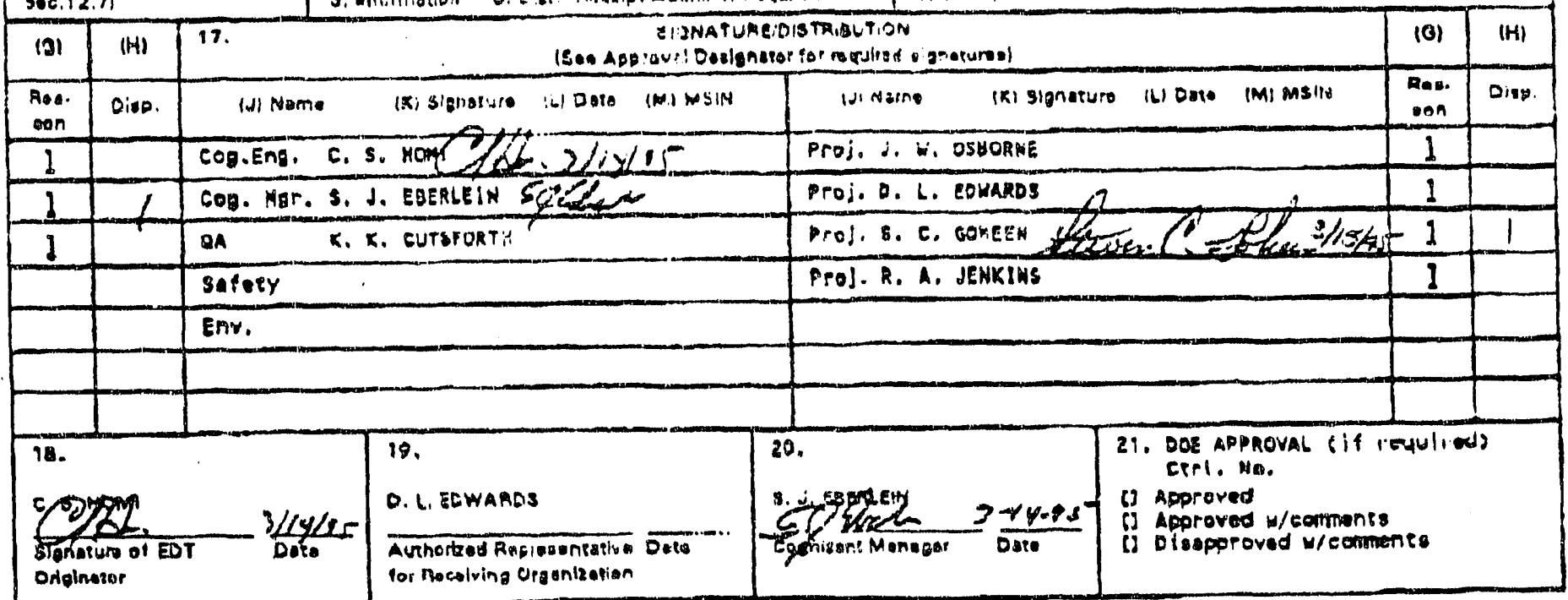




\begin{tabular}{|c|c|}
\hline $\begin{array}{l}\text { 3. TO: (Rocelving OroAnizasionz } \\
\text { SAMPLING AND MOBILE } \\
\text { LABORATORIES }\end{array}$ & $\begin{array}{l}\text { 3. Frep: coriginartm organizezlon) } \\
\text { THRS/CHARACTERIZATION SUPPORT }\end{array}$ \\
\hline 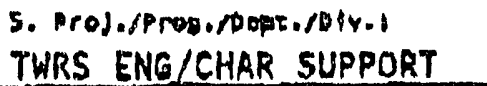 & $\begin{array}{l}\text { 6. Cog. Enari: } \\
\text { C. S. HOMI }\end{array}$ \\
\hline
\end{tabular}

6. OPPinator Romarko:

$N / A$

Post-il" brand lax transmillal merrig zort o of poos

11. Reediver Re
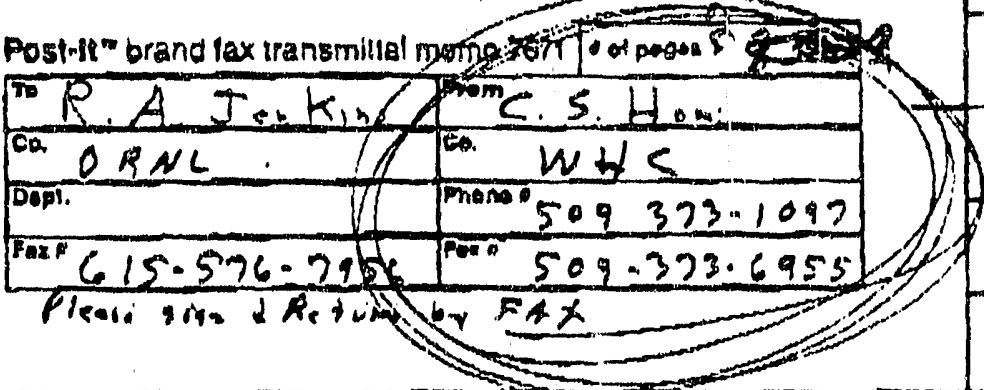

4. Ralaran EDT NO.

$N / A$

7. Pupehase Order Mo.:

$N / A$

9. Equip./Componert No.1

$N / A$

10. SYetempladg. /favibttyo $2750 E / 200 E$

12, Hejor Assm, Dug. Mo.:

$N / A$

13. Permit/Permis appllootion No.: $N / A$

16. Required Resporve Date: $03 / 26 / 95$

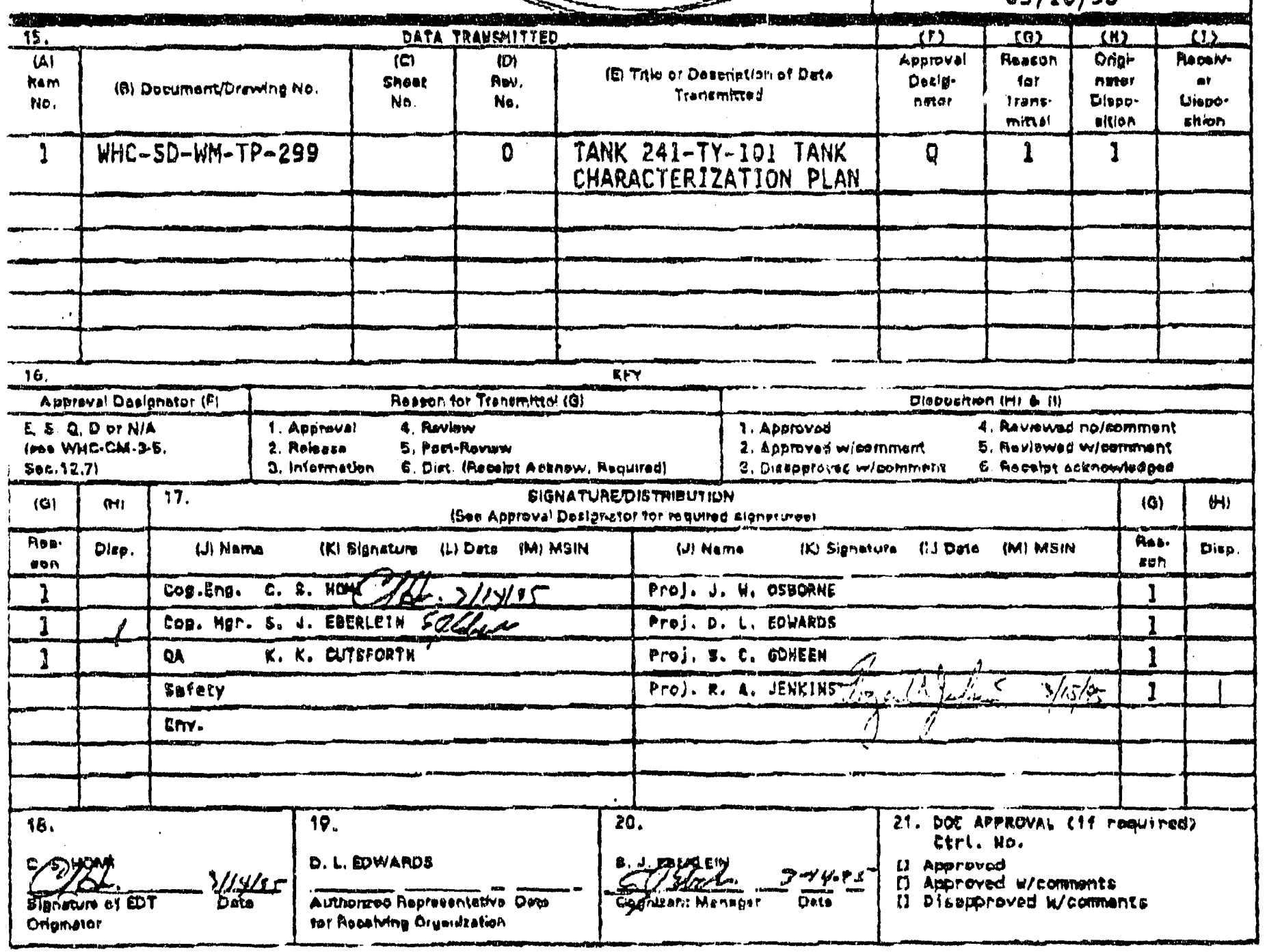

$\left.00-7400-172-2(04 / 9)_{1}\right)$ GEF007 


\section{RELEASE AUTHORIZATION}

Document Number: WHC-SD-WM-TP-299, REV 0

Document Title: TANK 241-TY-101 TANK CHARACTERIZATION PLAN

Release Date: $\quad 3 / 20 / 95$

This document was reviewed following the procedures described in WHC-CM-3-4 and is:

APPROVED FOR PUBLIC RELEASE

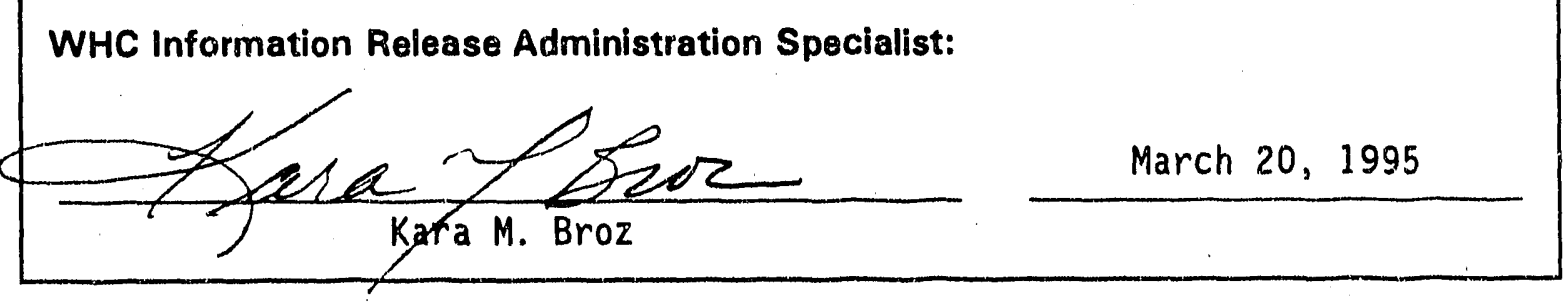

TRADEMARK DISCLAIMER. Reference herein to any specific commercial product, process, or service by trade name, trademark, manufacturer, or otherwise, does not necessarily constitute or imply its endorsement, recomendation, or favoring by the United States Goverrment or any agency thereof or its contractors or subcontractors.

This report hes been reproduced from the best available copy. Available in paper copy and microfiche. Printed in the United States of America. Available to the U.S. Department of Energy and its contractors from:

U.S. Department of Energy

Office of Scientific and Technical Information (OSTI)

P.O. Box 62

Oak Ridge, TN 37831

relephone: (615) 576.8401

Available to the public from:

U.S. Department of Commerce

National Technical information Service (NTIS)

5285 Port Royal Road

Springfield, VA 22161

Telephone: (703) $487-4650$ 


\begin{tabular}{|c|c|c|}
\hline $\begin{array}{l}\text { 2. Title } \\
\text { TANK 241-TY-101 TANK CHARACTERIZATION PLAN }\end{array}$ & $\begin{array}{l}\text { 3. Number } \\
\text { WHC-SD-WM-TP-299 }\end{array}$ & $\begin{array}{l}\text { 4. Rev No. } \\
0 \\
\end{array}$ \\
\hline $\begin{array}{l}\text { 5. KeY words } \\
\text { CHARACTERIZATION, DQO, HEALTH AND SAFETY VAPOR } \\
\text { ISSUE, FERROCYANIDE, FLAMMABLE, QUALITY CONTROL, } \\
\text { SINGLE-SHELL TANK, VAPOR SAMPLING, ANALYSIS, TANK } \\
\text { CHARACTERIZATION PLAN }\end{array}$ & 6. Author & $71520 / N 4168$ \\
\hline
\end{tabular}

\section{Abstract}

This document is a $\mathrm{plan}$ which serves as the contractual agreement between the Characterization Program, Sampling Operations, Oak Ridge National Laboratory, and PNL tank vapor program. The scope of this plan is to provide guidance for the sampling and analysis of vapor samples from tank 241-TY-101.

\section{DISCLAIMER}

This report was prepared as an account of work sponsored by an agency of the United States Government. Neither the United States Government nor any agency thereof, nor any of their employees, makes any warranty, express or implied, or assumes any legal liability or responsibility for the accuracy, completeness, or usefulness of any information, apparatus, product, or process disclosed, or represents that its use would not infringe privately owned rights. Reference herein to any specific commercial product, process, or service by trade name, trademark, manufacturer, or otherwise does not necessarily constitute or imply its endorsement, recommendation, or favoring by the United States Government or any agency thereof. The views and opinions of authors expressed herein do not necessarily state or reflect those of the United States Government or any agency thereof.

8. RELEASE STAMP

OFFICIAL RELEASE BY WHC

\section{DATE MAR 201995}

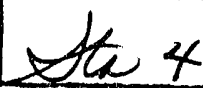




\title{
Tank 241-TY-101 \\ Tank Characterization Plan
}

\author{
Prepared for the U.S. Department of Energy \\ office of Environmental Restoration \\ and Waste Management
}


TABLE OF CONTENTS

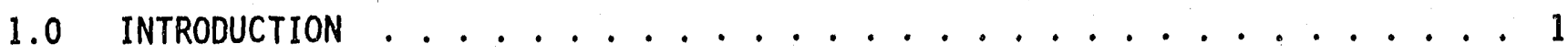

2.0 DATA QUALITY OBJECTIVES APPLICABLE TO TANK 241-TY-101 . . . . . . . . . . 1 2.1 SAFETY SCREENING DATA QUALITY OBJECTIVES . . . . . . . . . . . 1

2.2 WATCH LIST DATA QUALITY OBJECTIVES . . . . . . . . . . . . . . . 2

2.3 FUGITIVE VAPOR EMISSION DATA QUALITY OBJECTIVES $\ldots . . . . . . . . .2$

3.0 TANK HISTORICAL INFORMATION . . . . . . . . . . . . . . . . . 2

3.1 JANUARY 1995 TANK STATUS ................... 2

3.2 TANK CONFIGURATION ................... 3

3.3 TANK HISTORY .................... 3

3.4 EXPECTED TANK CONTENTS ..................... 3

4.0 STRATEGY FOR WASTE CHARACTERIZATION AND SAFETY ISSUE RESOLUTION . . . . . . 7

4.1 SAMPLING OF TANK TY-101 IN THE NEAR TERM ............ 7

5.0 REFERENCES ............................ 8

\section{APPENDICES}

A SAMPLING AND ANALYSIS PLAN FOR VAPOR SAMPLING IN FISCAL YEAR $1995 \ldots \ldots$

\section{LIST OF TABLES}

Table 1: Tank TY-101 Core Composite Chemical, Radiochemical, and Physical Characterization Data . . . . . . . . . . . . . . . . . 5

Table 2: Tank TY-101 Filtrate Chemical, Radiochemical, and Physical Characterization Data . . . . . . . . . . . . . . . . 6

Table 3: Integrated DQO Requirements ................. 7

\section{LIST OF FIGURES}

Figure 1: Fill History of Tank 241-TY-101 . . . . . . . . . . . . . . . 4 
AHC-SD-WM-TP-299, REV 0

\section{LIST OF ABBREVIATIONS}

DOE U.S. Department of Energy

DNFSB Defense Nuclear Facilities Safety Board

DQO Data Quality Objective

DST Double-Sheli Tank

HEPA High-Efficiency Particulate Air Filter

NCPLX Non-Complexed Waste

RCRA Resource Conservation and Recovery Act of 1976

SST Single-Shell Tank

TBP Tributyl Phosphate

TCP Tank Characterization Plan

TMACS Tank Monitor and Control System

TOC Total Organic Carbon

TPA Federal Facility Agreement and Consent Order (Tri-Party Agreement)

TWRS Tank Waste Remediation System

TY-101 Tank 241-TY-101

USQ Unreviewed Safety Question

WHC Westinghouse Hanford Company 


\subsection{INTRODUCTION}

The Defense Nuclear Facilities Safety Board (DNFSB) has advised the U.S. Department of Energy (DOE) to concentrate the near-term sampling and analysis activities on identification and resolution of safety issues (Conway 1993). The data quality objective (DQO) process was chosen as a tool to be used to identify sampling and analyitical needs for the resolution of safety issues. As a result, a revision in the Federal Facility Agreement and Consent Order (Tri-Party Agreement or TPA) milestone M44-00 has been made, which states that "A Tank Characterization Plan (TCP) will also be developed for each double-shell tank (DST) and single-shell tank (SST) using the DQO process... Development of TCPS by the DQO process is intended to allow users (e.g., Hanford Facility user groups, regulators) to ensure their needs will be met and that resources are devoted to gaining only necessary information." This document satisfies that requirement for tank 241-TY-101 (TY-101) sampling activities.

\subsection{DATA QUALITY OBJECTIVES APPLICABLE TO TANK 241-TY-101}

The sampling and analytical needs associated with the Hanford Site underground storage tariks on one or more of the four Watch Lists (ferrocyanide, organic, flammable gas, and high heat) and the safety screening of all 177 tanks have been identified through the DQO process. DQO's identify the information needed by a program group in the Tank Waste Remediation System (TWRS) concerned with safety issues, regulatory requirements, tank waste processing, or the transport of tank waste. As of January 1995, the DQO's that have been completed and may apply to TY-101 are discussed in the following sections.

Both Watch List and non-Watch List tanks will be sampled and evaluated to classify waste tanks in one of three categories: SAFE, CONDITIONALLY SAFE, or UNSAFE. A tank can be removed from a Watch List if it is classified as SAFE. The Watch List and other safety issue $D Q O^{\prime}$ 's identify the requirements used to determine which classification to place a tank, based on analyses that indicate if certain measures are above or below established thresholds. The measures begin with the determination of the concentration of primary analytes which have been considered indicators of potentially unsafe conditions within a tank. If a specific criteria level on one of these items is exceeded, further analysis and a possible change in tank classification, may be required.

\subsection{SAFETY SCREENING DATA QUALITY OBJECTIVES}

The Tank Safety Screening Data Quality Objective (Redus and Babad 1994) describes the sampling and analytical requirements that are used to screen waste tanks for unidentified safety issues. This DQO requires that a vertical profile of the tank waste be obtained from at least two widely spaced risers. This vertical profile may be obtained using core, auger, or grab samples. The primary analytical requirements for the safety screening of a tank are energetics, total alpha activity, moisture, and flammable gas concentiation. The safety screening analyses shall be applied to all core samples, DST Resource Conservation and Recovery Act (RCRA) samples, and auger samples, except those taken exclusively to assess the flammable gas crust burn issue. 


\subsection{WATCH LIST DATA QUALITY OBJECTIVES}

Based on the current classification of the tank, the Watch List. DQO applicable to tank TY-101 is Data Requirements for the Ferrocyanids Safety Issue Developed through the Data Quality Objective Process (Meacham et a1. 1994). The DQO for the ferrocyanide safety issue concluded that the most reliable information is obtained from two widely spaced core samples. Two primary parameters, sodium nickel ferrocyanide concentration and moisture content, determine whether a tank is SAFE, CONDITIONALLY SAFE, or UNSAFE.

\subsection{FUGITIVE VAPOR EMISSION DATA QUALITY OBJECTIVES}

The Tank Vapor Issue Resolution Program was initiated in 1992 to resolve the health and safety issues associated with the high level waste tanks at the Hanford Site. The two main issues related to this program are 1) an insufficient understanding of reported exposures of tank farm personnel to unacceptable levels of noxious vapors and 2) the risks to worker health and safety cannot be determined until the vapors in the waste tanks are well characterized. Westinghouse Hanford Company (WHC) standard safety practices dictate that any flammable components in the head space of any Watch List tank must ve determined and quantified before intrusive work can be conducted on these tanks. The DQO applicable to head space vapor sampling is Data Quality objectives for Generic In-Tank Health and Safety Vapor Issue Resolution (Osborne et al. 1994).

A nitrogen gas purge will be used to clear and cool the drill bit during rotary core sampling. This purge gas exhausts into the waste tank head space and over the operating period could potentially pressurize the head space resulting in an uncontrolled release of pullu'tants. A portable modular unit has been developed to exhaust the tank head space during rotary core sampling. This modular unit will remove airborne particies through high efficiency particulate air (HEPA) filters, but is not designed nor equipped to treat or remove toxic vapors. It is equipped with instruments to monitor and alarm for total organic carbon (TOC) and ammonia vapors. The tank head space must be characterized to confirm that the modular unit can be safely started and to establish acceptable TOC and ammonia levels for safe operation. The applicable DQO is Rotary Core Vapor Sampling Data Quaiity Objective (Price 1994).

Tank TY-101 is one of the 36 tanks on the "Suspect Tank List" (Osborne and Huckaby 1994b). This list is composed of Ferrocyanide and Organic Watch List tanks, plus seven tanks with a history of vapor incidents.

\subsection{TANK HISTORICAL INFORMATION}

This section summarizes the available information for tank TY-101. Included are the present status and physical description of the tank, its age, process history, and the expected contents of the tank based on historical information.

\subsection{JANUARY 1995 TANK STATUS}

Tank TY-10i was officially added to the Ferrocyanide Watch List in January 1991. The amount of FeCN reported for the tank is 23,000 g-mol. The tank waste temperature is monitored continuously by the Tank Monitor and Control System (TMACS). The highest waste temperature reading taken on October 27,1994 , from riser $\# 4$, was $22^{\circ} \mathrm{C}\left(72^{\circ} \mathrm{F}\right)$, which did not exceed the maximum temperature criteria (Hanton 1994).

This tank currently contains non-complexed (NCFLX) waste with a total waste volume 
of 447,000 ? iters ( 118,000 gallons), whicli is equivalent to 97 centimeters ( 38 inches) of waste as measured from the baseline of the tank. The current surface level, as read manually and on a quarterly basis with a fond instrument corporation gauge located on riser \#1, is 125 centimeters (49.2 inches). The waste is comprised entirely of sludge, with no supernatant liquid or saltcake present (Hanlon 1994).

\subsection{TANK CONFIGURATION}

Tank TY.101 is one of six single-shell tanks in the 2.00 West Area TY Farm. Tank TY-101 is 23 meters ( 75 feet) in diameter and 7 meters (23 feet) in operating depth. It has a concave-shaped base and a design capacity of 2.87 million iiters $(758,000$ gallons). However, safety considerations requirs a maximum operating capacity of 2.84 nillion liters $(750,000$ gallons). The tank has three active dry wells monitoring radiation in the surrounding soil (Hanion 1994).

The tank is first in a cascade flow series consisting of tanks TY-101 and 241-TY102. A cascade system consists of tanks connected in series by pipes. When the primary tank in the system became full, the waste would then flow to the secondary tanks in the system.

\subsection{TANK HISTORY}

Tank TY-101 was constructed betwaen 1951 and 1952 and was put into service in 1953. Initiaily tank TY-101 received 2.87 million liters $(758,000$ gallons) of evaporator bottoms waste. In 1954, the tank began receiving first cycle decontamination waste from the $\mathrm{BiPO}_{4}$ prosess from $B$ Plant and $\mathrm{T} P 7$ art. In 1955, supernate was pumped to tank 241-TY-118. Tank TY-101 continued to receive jecontamination waste through 1959. During the third quarter of 1959, tank TY-101 received waste from tank 241-TY-106 consisting of tributyl phosphate (TBP) uranium extraction process waste from U Plant. In 1967, iank TY-101 received from tank $241-5 X-103$ high-1evel waste from the reduction oxidation process. From 1973 to 1975, because of suspected leaks, a series of

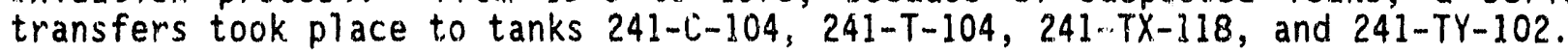

The tank was classified as a suspect leaker in 1974, was removed from service in 1975, and was ?abeled inactive in 1977. Tank TY-101 is passively ventilated. Primary stabilizatiof on the tank was completed in 1978. The tank is of questionable integrity. The last solids volume update was obtained on April 28, 1982 and the 7 ast photo was taken on August 22, 1989. Figure 1 summarizes the influx and effluent history or tank TY-101 (Anderson 1990).

\subsection{EXPECTED TANK CONTL:TS}

The contents of tank TY-101 are expecsed to consist of a two-layered sludge. The bottom layer is approximacely 26,500 liters $(7,000$ gallons) of first cycle decontamination and TBP waste. The top layer is TBP waste from the REDOX separation process (Winters 1990). Some evaporator bottoms waste was added to tank TY-101 early in its operating life, but may not form a distinct layer due to the large number of transfers to and from the tank. Weiss and Mauss 11987) riescribes three visually distinct layers (brown on top, changing to white in the middle, and becoming green on the bottom), but does not adtress the possible origins of the layers. Tables 1 and 2 summarize the musi curient characterization data and the results of a core composite analysis, performed at the 222-S Laboratory, for tank TY-101 (Weiss and Mauss 1987). 
Figure 1: Fill History of Tank 241-TY-101
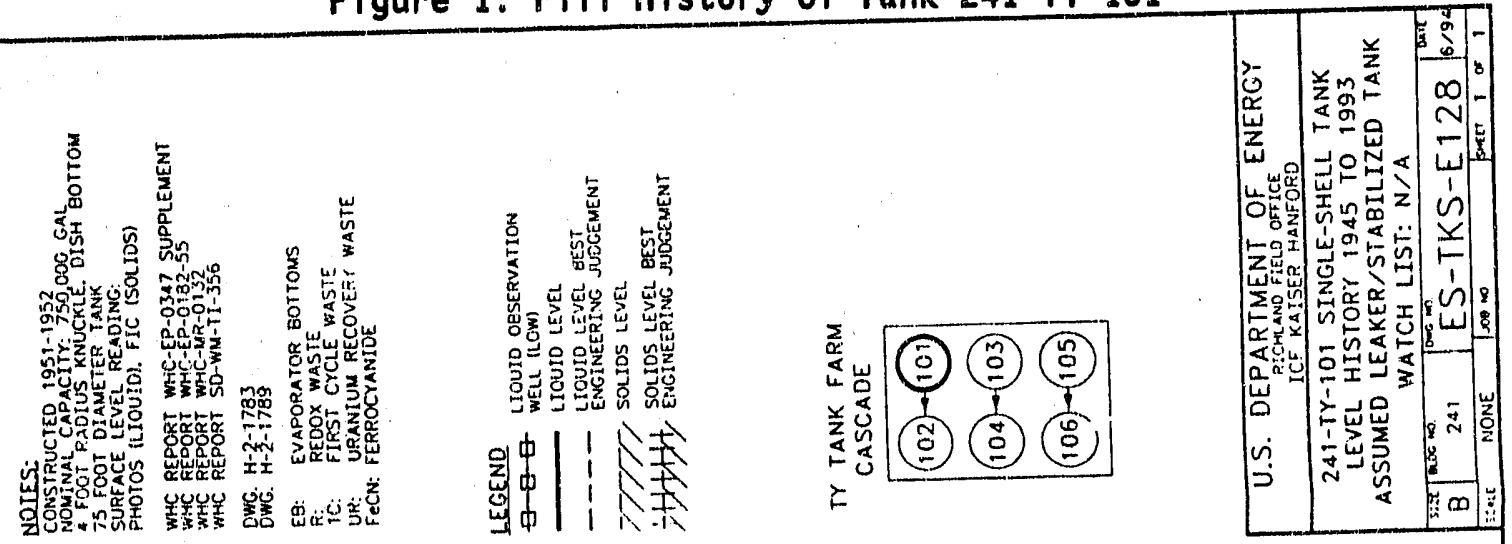

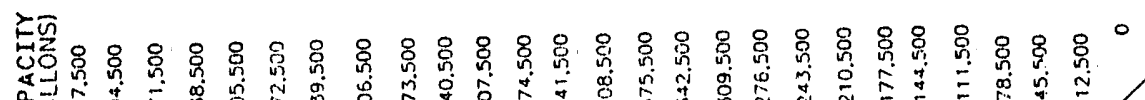

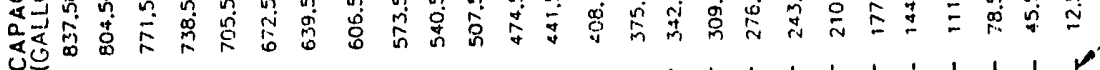
sิ

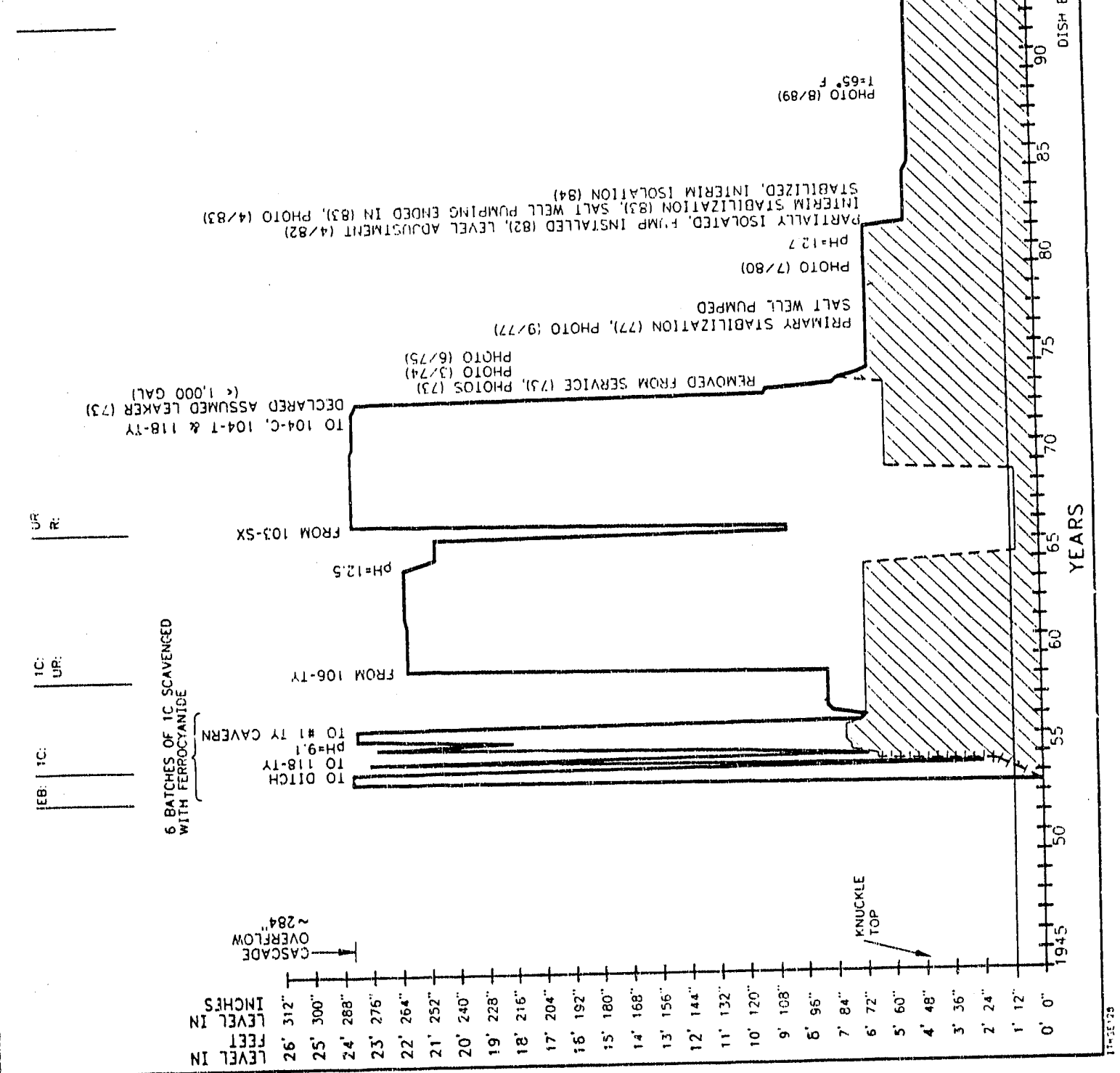


WHC-SD-WM-TP-299, REV O

Table 1: Tank TY-101 Core Composite Chemical, Radiochemical, and Physical Characterization Data

\begin{tabular}{|c|c|c|}
\hline Physical Data & \multicolumn{2}{|c|}{ Value } \\
\hline Total Solid Wast: & \multicolumn{2}{|c|}{$732,000 \mathrm{~kg}(118,000 \mathrm{gallons})$} \\
\hline Radiation & \multicolumn{2}{|c|}{$10 \mathrm{mR} /$ hour } \\
\hline Specific Heat & \multicolumn{2}{|c|}{$0.6 \mathrm{~J} / \mathrm{g}^{\circ} \mathrm{C}$} \\
\hline Bulk Density & \multicolumn{2}{|c|}{$1.64 \mathrm{~g} / \mathrm{ml}$} \\
\hline Particle Size & \multicolumn{2}{|c|}{$8.2 \mu \mathrm{m}$} \\
\hline Viscosity & \multicolumn{2}{|c|}{$10,000 \mathrm{cP}$} \\
\hline $\mathrm{pH}$ & \multicolumn{2}{|c|}{8.2} \\
\hline Total Organic Carbon & \multicolumn{2}{|c|}{$1,090,000 \mu \mathrm{g} / 1$} \\
\hline Analytes & $\mu g / g$ & $\mu \mathrm{g} / \mathrm{ml}$ \\
\hline $\mathrm{Na}$ & 121,000 & 198,000 \\
\hline A1 & 29,100 & 47,700 \\
\hline $\mathrm{Ba}$ & 1,920 & 3,150 \\
\hline $\mathrm{NO}_{3}$ & 145,000 & 238,000 \\
\hline $\overrightarrow{\mathrm{Bi}}$ & 27,200 & 44,600 \\
\hline $\mathrm{Cd}$ & 8.66 & 14.2 \\
\hline $\mathrm{Cr}$ & 8,410 & 13,800 \\
\hline $\mathrm{Fe}$ & 40,200 & 65,900 \\
\hline$F$ & 3,370 & 5,530 \\
\hline $\mathrm{Cl}$ & 756 & 1,240 \\
\hline $\mathrm{Pb}$ & 218 & 358 \\
\hline$M n$ & 542 & 889 \\
\hline $\mathrm{Ni}$ & 5,100 & 8,360 \\
\hline$p$ & 25,300 & 01,500 \\
\hline Si & 38,700 & 63,500 \\
\hline$\overline{\mathrm{Ag}}$ & 3.85 & 6.31 \\
\hline $\mathrm{Zr}$ & 377 & 618 \\
\hline U & 2,330 & 3,820 \\
\hline Radionuclides & $\mu \mathrm{Ci} / \mathrm{g}$ & $\mu \mathrm{Ci} / 1$ \\
\hline Total Gamma & 0.284 & 466 \\
\hline${ }^{99} \mathrm{TC}$ & 0.007 & 12.1 \\
\hline $239 / 240 \mathrm{Pu}$ & 0.191 & 313 \\
\hline${ }^{137} \mathrm{Cs}$ & 0.284 & 466 \\
\hline${ }^{90} \mathrm{Sr}$ & 12.4 & 20,300 \\
\hline
\end{tabular}

${ }^{1}$ (Weiss and Mauss 1987) 
WHC-SD-WM-TP-299, REV O

Table 2: Tank TY-101 Filtrate Chemical, Radjochemi,al, and Physical Characterization Data

\begin{tabular}{|c|c|c|c|c|}
\hline \multicolumn{3}{|c|}{ Chemical Components } & \multicolumn{2}{|c|}{ Physical Data } \\
\hline Component & $\mu \mathrm{g} / \mathrm{ml}$ & $w t \%$ & $\%$ Water & 90.8 \\
\hline $\mathrm{NaAlO}_{2}$ & 32.8 & 0 & Specific Gravity & 1.09 \\
\hline $\mathrm{NaOH}$ & 2000 & 0.18 & & \\
\hline $\mathrm{NaNO}_{2}$ & 2760 & 0.24 & & \\
\hline $\mathrm{NaNU}_{3}$ & 107,000 & 9.82 & & \\
\hline $\mathrm{Na}_{2} \mathrm{CO}_{3}$ & 1,060 & 0.1 & Radiochemical & onents \\
\hline TOC & 0.2 & 0.06 & Component & $\mu \mathrm{Ci} / 1$ \\
\hline $\mathrm{NaPO}_{a}$ & 18,000 & 1.68 & ${ }^{137} \mathrm{Cs}$ & 77.0 \\
\hline $\mathrm{Na}_{2} \mathrm{SO}_{4}$ & 5,630 & 0.54 & ${ }^{90} \mathrm{sr}$ & 10.4 \\
\hline
\end{tabular}

1 (Weiss and Mauss 1987) 


\subsection{STRATEGY FOR WASTE CHARACTERIZATION AND SAFETY ISSUE RESOLUTION}

The DQO requirements for sampling and analyses are integrated and compared with scheduled sampling and analysis activities in this section.

\subsection{SAMPLING OF TANK TY-101 IN THE NEAR TERM}

The characterization objectives in fiscal year 199! involve sampling of tanks to identify and resolve safety issues. Head space vapor sal 17 ing in April 1995 and rotary core sampling in June 1995 are scheduled for tank $T-101$. No other sampling is scheduled through fiscal year 1997 (Stanton 1994). The head space vapor sampling shall be conducted following Data Quality Objectives for Generic In-Tank Health and Safety Vapor Issue Resolution (Osborne et a1. 1994) and Rotary Sampling Core Vapor Sampling Data Quality objective (Price 1994). Vapor sampling will satisfy part of the requirement specified in TPA Milestone M-40-08 to complete the vapor sampling of all Ferrocyanide Watch List tanks (Osborne and Huckaby 1994b).

Rotary core sampling shall be conducted following Tánk Safety Screening Data Quality Objective (Redus and Babad 1994) and Data Requirements for the Ferrocyanide Safety Issue Developed Through the Data Quality Objective Process (Meacham et al. 1994). These two sampling and analysis events, if successful, will also satisfy the January 1995 applicable DQO requirements. These requirements are summarized in Table 3. A more complete list of analytical requirements are given as an appended revision, in the appropriate sampling and analysis plan.

Table 3: Integrated DQO Requirements

\begin{tabular}{||l|l|l|l||}
\hline $\begin{array}{l}\text { Sampling } \\
\text { Event }\end{array}$ & Applicable DQO & Sampling Requirements & Analytical Requirements \\
\hline $\begin{array}{l}\text { Vapor } \\
\text { Sampling }\end{array}$ & $\begin{array}{l}\text {-Health \& Safety Vapor } \\
\text { Issue Resolution DQO } \\
\text {-Rotary Sampling Core } \\
\text { Vapor Sampling DQO }\end{array}$ & $\begin{array}{l}\text { 3 SUMMA@ canisters } \\
\text { 6 Sorbent Trap Systems }\end{array}$ & $\begin{array}{l}\text { Gas Flammability } \\
\text { Gas Toxicity } \\
\text {-Organic Vapors } \\
\text {-Permanent Gases }\end{array}$ \\
\hline $\begin{array}{l}\text { Rotary } \\
\text { Sampling }\end{array}$ & $\begin{array}{l}\text {-Safety Screening DQO } \\
\text {-Ferrocyanide DQO }\end{array}$ & $\begin{array}{l}\text { 2 core samples from } \\
\text { risers separated } \\
\text { radially to the maximum } \\
\text { extent possible }\end{array}$ & $\begin{array}{l}\text { Energetics, TOC, Total } \\
\text { Alpha, Beta \& Gamma, } \\
\text { Moisture, CN, Major } \\
\text { Anions \& Cations, TIC, } \\
\text { Radionuclides, Density, } \\
\text { Flammable Gas } \\
\text { Concentrations }\end{array}$ \\
\hline
\end{tabular}

SUMMA is a Registered Trademark of Oregon Graduate Institute of Science and Technology 


\section{WHC-SD-HM-TP-299, REV 0}

\subsection{REFERENCES}

Anderson, J. D., 1990, A History of the 200 Area Tank Farms, WHC-MR-0132, Westinghouse Hanford Company, Richland, Washington.

Conway, J.T., Letter to H.R. O'Leary, DOE, "DNFSB Recommendation 93-5 to the Secretary of Energy." 9400070, dated July 19, 1993.

Hanion, B.M., 1994, Waste Tank Sumnary for Month Ending October 31, 1994, WHC-EP0182-79, Westinghouse Hanford Company, Richland, Washington.

Meacham, J. E., R. J. Cash, G. T. Dukelow, H. Babad, J. W. Buck, C. M. Anderson, D. D. Mahlum, B. A. Pulsipher, J. Y. Young, 1994, Data Quality Objective for Generic InTank Health and Safety Vapor Issue Resolution, WHC-SD-WM-DQ0-002, ReV. 0, Westinghouse Hanford Company, Richland, Washington.

Osborne, J.W., J.L. Huckaby, E.R. Hewitt, C.M. Anderson, D.D. Mahlum, B.A. Pulsipher, J.Y. Young, 1994, Data Quality Objectives for Generic In-Tank Health and Safety Vapor Issue Resolution, WHC-SD-WM-DQ-002, Rev. 0, Westinghouse Hanford Company, Richland, Washington.

Osborne, J. W. and J. L. Huckaby, 1994b, Program Plan for the Resolution of Tank Vapor Issues, WHC-EP-0562, Rev. 1, May 1994, Westinghouse Hanford Company, Richland, Washington.

Price, D.N., 1994, Rotary Core Vapor Sampling Data Quality Objective, WHC-SD-WM-SF-004, Westinghouse Hanford Company, Richland, Washington.

Redus, K.S., H. Babad, 1994, Tank Safety Screening Data Quality Objective, WHC-SD-WMSP-004, Westinghouse Hanford Company, Richland, Washington.

Stanton, G. A., 1994, Baseline Sampling Schedule, Revision 3, (internal memo 7R320-9403, to distribution, September 22), Westinghouse Hanford Company, Richland, Washington.

Weiss, R.L., B.M. Mauss, 1987, Data Transmittal Package for 241-TY-101 Waste Tank Characterization, SD-RE-TI-185, Rockwell Hanford Operations, Richland, Washington.

Winters, W. I., L. Jensen, L. M. Sasaki, R. C. Weiss, J. F. Keller, A. J. Schmidt, and M. G. Woodruff, 1990, Waste Characterization Plan for the Hanford Site Single-Shell Tanks, WHC-EP-0210, Rev. 2, Westinghouse Hanford Company, Richland, Washington. 
WHC-SD-WM-TP-299, REV 0

APPENDIX A

TAAKK TY-101

SAMPLING AND ANALYSIS PLAN FOR

VAPOR SAMPLING IN FISCAL YEAR 1995

$A-i$ 
WHC-SD-WM-TP-299, REV 0

CONTENTS

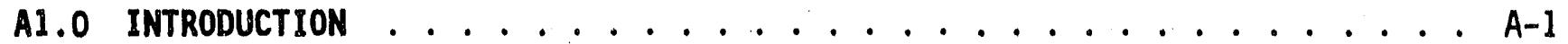

A2.0 SAMPLING AND ANALYSIS SCHEME ................ A-1

A2.1 VAPOR SAMPLING EVENT .................. . . . . . .

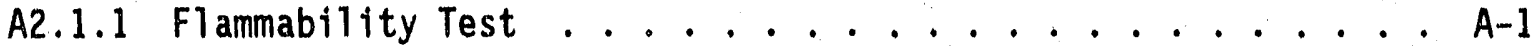

A2.1.2 Sample Collection Using SUMMA Canisters And Sorbent

A2.1.3 Radiation Screening and Sample Transport $\therefore \ldots A-\ldots$ A2.2 LABORATORY ANALYSIS .................... A-5

A2.2.1 Preparation of Sample Media Containers . . . . . . . . A-5

A2.2.2 Sample Analysis ................ A-5

A2.2.3 Insufficient Samples . . . . . . . . . A-5

A3.0 QUALITY ASSURANCE \& QUALITY CONTROL . . . . . . . . . . . A A-8 A3.1 Sampling Operations . . . . . . . . . . . . . A-8

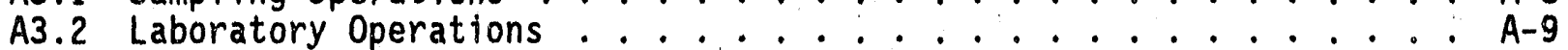

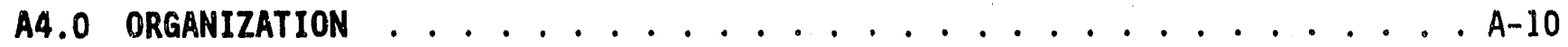

A5.0 EXCEPTIONS, CLARIFICATIONS, AND ASSUMPTIONS . . . . . . . . A-10

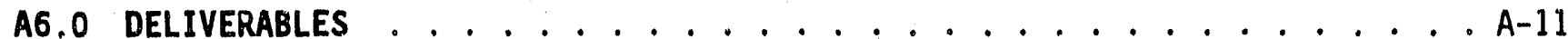

A6.1 Format I Reporting . . . . . . . . . . . . . A A-12

A6.2 Format II Reporting ...................A-12

A6.3 Format VI Reporting . . . . . . . . . . . . . . A-12

A7.0 CHANGE CONTROL . . . . . . . . . . . . . . . . A-13

A8.0 REFERENCES . . . . . . . . . . . . . . . . . A-14

\section{LIST OF TABLES FOR APPENDIX A}

Table A-1: General Sampling Information . . . . . . . . . . . A-2

Table A-2: List of Samples and Activities for Tank TY-101. . . . . . . . A-3

Table A-3: Limits For Acceptable Radionuclide Activity Levels. . . . . . . A-4

Table A-4: TY-101 Sample Chemical, Radiological, and Physical Analytical

Requirements .............. A-7

Table A-5: Tank TY-101 Project Key Personnel List. . . . . . . . . . . . . A-10

\section{LIST OF FIGURES FOR APPENDIX A}

Figure A-1: Test Plan Outline and Flowchart for Tank Vapor Space Characterization. 


\section{LIST OF ACRONYMS FOR APPENDIX A}

$\begin{array}{ll}\text { BEL } & \text { Biological Exposure Limit } \\ \text { CERCLA } & \text { Comprehensive Environmental Response, Compensation, and Liability Act of } 1980 \\ \text { CES } & \text { Consensus Exposure Standards } \\ \text { CGM } & \text { Combustible Gas Meter } \\ \text { DOT } & \text { Department of Transportation } \\ \text { DQO } & \text { Daca Quality Objective } \\ \text { EPA } & \text { Environmental Protection Agency } \\ \text { ESH\&QA } & \text { Environmental Safety, Health, and Quality Assurance } \\ \text { GC/MS } & \text { Gas Chromatography/Mass Spectrometry } \\ \text { HEPA } & \text { High-Efficiency Particulate Air Filters } \\ \text { IC } & \text { Ion Chromatography } \\ \text { IDLH } & \text { Immediately Dangerous to Life and Health } \\ \text { LFL } & \text { Lower Flammability Limit } \\ \text { ORNL } & \text { Oak Ridge National Laboratory } \\ \text { PEL } & \text { Permissible Exposure Limit } \\ \text { PNL } & \text { Pacific Northwest Laboratory } \\ \text { PPBV } & \text { parts per billion by volume } \\ \text { PPMV } & \text { parts Ner milion by volume } \\ \text { QAPP } & \text { Quality Assurance Project Plan } \\ \text { RCRA } & \text { Resource Conservation and Recovery Act } \\ \text { SAP } & \text { Sampling and Analysis Plan } \\ \text { SML } & \text { Sampling and Mobile Laboratories } \\ \text { SUMMA@ } & \text { registered trademark for passivated stainless steel canister of the Oregon } \\ & \text { Graduate Institute of Science and Technology } \\ \text { TCP } & \text { Tank Characterization Plan } \\ \text { TLV } & \text { Threshold Limit Value } \\ \text { TNMHC } & \text { Total Non-Methane Hydrocarbons } \\ \text { TO-14 } & \text { EPA Toxics Organics Protocol 14 } \\ \text { TRP } & \text { Toxicology Review Panel } \\ \text { TST } & \text { Triple Sorbent Trap } \\ \text { TWRS } & \text { Tank Waste Remediation System } \\ \text { TWAP } & \text { Tank Waste Analysis Plan } \\ \text { TY-101 } & \text { Tank 24l-TY-101 } \\ \text { VSS } & \text { Vapor Sampling System } \\ \text { WHC } & \text { Westinghouse Hanford Company } \\ & \end{array}$




\section{A1.0 INTRODUCTION}

Tank 241-TY-101 (TY-101) is scheduled to be sampled for flammability and toxicity of vapor in the headspace of the tank. This Appendix $A$ is intender to address only the scheduled vapor sampling and analysis for the fiscal year 1995. Plesent vapor sampling systems include Type 2 (In Situ Sampling, or ISS) and Type 3 (the Vapor Sampling system, or VSS). These two sampling systems are operated by Sampling and Mobile Laboratories (SML). Both the VSS and ISS collect condensible and non-condensible gases from the tank, they just do it differently. The VSS used a heaced vapor probe and collects the sample out of the tank. The ISS lowers the sorbents and TST into the tank headspace for the condensible gases and collects SUMMA®s out of the tank for permanent gases.

\section{A2.0 SAMPLING AND ANALYSIS SCHEME}

The following sections provide the methodology and procedures to be used in the preparation, retrieval, transport, analysis, and reporting of results from vapor samples retrieved from tank TY-101. The requirements for this sample event, contained within this appendix of the TCP, are within the scope of work specified in the appropriate laboratory work authorizing documents. Any decisions, observations, or deviations to this sampling and analysis plan made during sample receipt, preparation and analysis shall be documented in controlled notebooks and justified in the deliverable report. The general sampling and analysis scheme for Type 3 vapor sampling is presented as a flowchart and narrative in Figure $A-1$.

\section{A2.1 VAPOR SAMPLING EVENT}

The responsibilities of Sampling and Mobile Laboratories (SML) to this sampling event are given in this section. For detailed information regarding applicable operating procedures for the tank TY-101 vapor sampling activity refer to work package WS-95-00018. Additional quality control and deliverable requirements are given in Sections $A 3.0$ and $A 6.0$. of this appendix.

\section{A2.1.1 Flammability Test}

Prior to this sampling event and any intrusive work on this tank, an assessment of the flammability of the tank head space gases is required by WHC safety practices. The flammability test is performed by Industrial Hygiene Field Services using a combustible gas meter (CGM). The procedure for this flammability test is included in the sampling event work package.

- If the tank vapor fuel content is greater than or equal to $20 \%$ of the lower flammability limit (LFL) under steady state conditions, then all sampling activities must stop until further authorization is given by management.

- If CGM measures a total fuel content between $10 \%$ and $20 \%$ of the LFL, vapor sampling activity may continue under CGM monitoring to better identify the hazard level.

- If the concentration is below $10 \%$ of the $L F L$, the tank is not considered have a flammability hazard and all sampling work can proceed (Ostorne 1994). 


\section{A2.1.2 Sample Collection Using SUMMA Canisters And Sorbent Tubes}

SML shall provide sample identification numbers to the laboratories according to the format given in Section A3.1. SML shall use labeled sample containers supplied by the laboratory (see Section A2.2.1, Preparation of Sample Media Containers) to collect vapor samples. The VSS shall be used to collect vapor from tank TY-101 in accordance with SML procedure WHC-IP-1127(4.5) "Collection of SUMMA® Canisters and Sorbent Tube Sampling Using the Vapor Sampling System (VSS)". The sample type, type of collection media to be used, and the number of samples requested are given in Table $A-1$.

Table A-1: General Sampling Information

\begin{tabular}{|c|c|c|c|c|}
\hline Sample Container & Prepared By & $\begin{array}{l}\text { Preparation } \\
\text { Procedure }\end{array}$ & Sample Type & $\begin{array}{c}\text { Number of } \\
\text { Samples }\end{array}$ \\
\hline SUMMAO & PNL & PNL-TVP-02 & Tank Air & 3 \\
\hline SUMMA@ & PNL & PNL-TVP-02 & Ambient Air & 2 \\
\hline \multirow[t]{3}{*}{$\begin{array}{l}\text { Triple Sorbent Traps } \\
\text { (TST) }\end{array}$} & ORNL & $\begin{array}{c}\text { AC-OP-300-0907 } \\
\text { CASD-AM-300-WPO1 } \\
\end{array}$ & Tank Air & 12 \\
\hline & ORNL & $A C-0 P-300-0907$ & Field Blank & 2 \\
\hline & ORNL & $A C-0 P-300-0907$ & Trip Blank & 2 \\
\hline \multirow{2}{*}{$\begin{array}{l}\text { Sorbent Trap System } \\
\text { for } \mathrm{NH}_{3}, \mathrm{NO}_{2}, \mathrm{NO}, \mathrm{H}_{2} \mathrm{O}\end{array}$} & PNL & PNL-TVP-09 & Tank Air & 6 \\
\hline & PNL & PNL-TVP-09 & Trip Blank & 3 \\
\hline Tritium Trap & WHC & $L A-548-111$ & Tank Air & 1 \\
\hline HEPA Filters & WHC & $N / A$ & Tank Air & 4 \\
\hline
\end{tabular}

'One sample taken through the VSS, one sample taken upwind of the tank.

${ }^{2}$ Preparation procedure for samples spiked with surrogate(s).

Table A-2 provides a sequence of sampling activities along with sample collection times and the flow rates through sample collection tubes: A cleanliness check of the sampling system shall be performed in accordance with procedure WHC-IP-1127(4.5) Appendix C. A cleanliness check of the VSS shall also be performed by collecting ambient air SUMMA@ samples prior to sampling the tanks using the following conditions: 1) with the VSS manifold and transfer line fully heated, and 2) without the VSS, upwind of tank TY-101.

Organic vapors shall. be monitored using the GC/FID during the sampling event. The operating procedure for the GC/FID is provided in the procedure WHC-IP-1127(4.5) and Bellus (1993). The sampling team is responsible for documenting any problems and procedural changes affecting the validity of the sample in a field notebook. 
Table A-2. List of Samples and Activities for Tank TY-101.

\begin{tabular}{|c|c|c|c|c|}
\hline SAMPLE CODE & SAMPLE/ACTIVITY DESCRIPTION & $\begin{array}{l}\text { SAMPLER POSITION } \\
\text { DURIHG COLLEECTION }\end{array}$ & GAS FLOW RATE & $\begin{array}{l}\text { SAMPLE } \\
\text { DURATION }\end{array}$ \\
\hline$\cdots$ & Adjust vss temperature setpoint to $40^{\circ} \mathrm{C}$ & $N / A$ & $N / A$ & $N / A$ \\
\hline$\cdots$ & Purge VSS with ambient air ${ }^{2}$ & $N / A$ & $5,450 \mathrm{~mL} / \mathrm{min}$ & $30 \mathrm{~min}$. \\
\hline 01 & Collect ambient air sample SUMMA \#1 & Upwind of TY-101 & N/A & $1 \mathrm{~min}$. \\
\hline$\cdots$ & Perform cleanl iness check" & $N / A$ & N/A & $N / A$ \\
\hline 02 & Collect ambient air sample SUMMA \#2 & Port 15 & $N / A$ & $1 \mathrm{~min}$. \\
\hline$\because$ & Leak test & $N / A$ & N/A & N/A \\
\hline$\because$ & Purge Vss with tank air & $N / A$ & $5,450 \mathrm{~mL} / \mathrm{min}$ & $30 \mathrm{~min}$. \\
\hline$\cdots$ & Measure tank pressure & $N / A$ & N/A & M/A \\
\hline 03 & Collect Tritium Trap & Sorbent line 8 & $200 \mathrm{~mL} / \mathrm{min}$ & $5 \min$. \\
\hline$\cdots$ & Collect GC sample and initiate GC run ${ }^{3}$ & $N / A$ & $N / A$ & N/A \\
\hline 04 & Collect SUMMA \#3 & Port 11 & N/A & 1 min. \\
\hline 05 & Collect SUMMA \#4 & Port 13 & N/A & 1 min. \\
\hline 06 & Collect SUMMA & Port 15 & $N / A$ & $1 \mathrm{~min}$. \\
\hline 07 & Collect Triple sorbent irap (TST) sample \#1 & Sorbent line 9 & $50 \mathrm{~mL} / \mathrm{min}$ & 4 min. \\
\hline 08 & Collect TST sample \#2 & Sorbent line 10 & $50 \mathrm{~mL} / \mathrm{min}$ & $4 \mathrm{~min}$. \\
\hline 09 & Collest TST sample $\# 3$ & Sorbent line 8 & $50 \mathrm{~mL} / \mathrm{min}$ & $4 \min$. \\
\hline 10 & Open, close, \& store ist field Blank \#1 & Ir, vss truck & $0 \mathrm{~mL} / \mathrm{min}$ & N/A \\
\hline 11 & Collect TST sample \#4 & Sorbent line 10 & $50 \mathrm{~mL} / \mathrm{min}$ & $4 \min$. \\
\hline 12 & Collect TST sample \#5 & Sorbent line 9 & $200 \mathrm{~mL} / \mathrm{min}$ & $5 \min$. \\
\hline 13 & Collect TST sample \#6 & Sorbent line 10 & $200 \mathrm{~mL} / \mathrm{min}$ & $5 \min$. \\
\hline 14 & Collect TST sample \#T & Sorbent line 8 & $200 \mathrm{~mL} / \mathrm{min}$ & $5 \min$. \\
\hline 15 & Collect TST sample \#B & Sorbent line 10 & $200 \mathrm{~mL} / \mathrm{min}$ & $5 \mathrm{~min}$. \\
\hline 16 & Collect TST sample $\# 9$ & Sorbent line 9 & $200 \mathrm{~mL} / \mathrm{min}$ & 20 min. \\
\hline 17 & Open, close, \& store TST Field Blank \#2 & In Vss truck & $0 \mathrm{~mL} / \mathrm{min}$ & N/A \\
\hline 18 & Collect YST sample \#10 & Sorbent line 10 & $200 \mathrm{~mL} / \mathrm{min}$ & 20 min. \\
\hline 19 & Collect TST sample \#11 & Sorbent line 8 & $200 \mathrm{~mL} / \mathrm{min}$ & 20 min. \\
\hline 20 & Collect TST sample \#12 & Sorbent line 10 & $200 \mathrm{~mL} / \mathrm{min}$ & $20 \mathrm{~min}$. \\
\hline 21,22 & Store TST Trip Blanks \#1 \& \#2 & None & None & None \\
\hline 23 & Collect NH3/NOX/H2O Sorbent Trap \#1 & sorbent line 9 & $200 \mathrm{~mL} / \mathrm{min}$ & 15 min. \\
\hline 24 & Collect NH3/NOx/H2O Sorbent Trap $\$ 2$ & Sorbent line 10 & $200 \mathrm{~mL} / \mathrm{min}$ & $15 \mathrm{~min}$. \\
\hline 25 & Collect NH3/NOX/H2O Sorbent Trap \#3 & Sorbent line 8 & $200 \mathrm{~mL} / \mathrm{min}$ & 15 min. \\
\hline 26 & Col'ect NH3/NOX/H2O Sorbent Trap H4 & Sorbent line 10 & $200 \mathrm{~mL} / \mathrm{min}$ & 15 min. \\
\hline 27 & Col ect NH3/NOX/H2O Sorbent Trap \#5 & Sorbent line 9 & $200 \mathrm{~mL} / \mathrm{min}$ & $15 \mathrm{~min}$. \\
\hline 28 & Collect NH3/NOX/H2O Sorbent Trap \#6 & Sorbent line 10 & $200 \mathrm{~mL} / \mathrm{min}$ & 15 min. \\
\hline $29,30,39$ & $\begin{array}{l}\text { Store NH3/NOX/H2O Trap Trip Blanks } \# 1 \text {, } \\
\$ 2, \& \$ 3\end{array}$ & Wone & None & None \\
\hline 32 & $\begin{array}{l}\text { Remove upstream HEPA filter from HEPA } \\
\text { transfer box }\end{array}$ & Upstream of box & \multicolumn{2}{|c|}{ Continuous } \\
\hline 33 & $\begin{array}{l}\text { Remove downstream HEPA Filter from HEPA } \\
\text { transfer box }\end{array}$ & Downstream of box & \multicolumn{2}{|c|}{ Cont inuous } \\
\hline 34 & Remove upstream HEPA Filter from vss & Upstream of VSS & \multicolumn{2}{|c|}{ Cont inuous } \\
\hline 35 & Remove downstream HEPA filter from vSS & Downstream of vSS & \multicolumn{2}{|c|}{ Continuous } \\
\hline
\end{tabular}

1 Current $(12 / 12 / 94)$ waste temperature is $22.0^{\circ} \mathrm{C}$.

2 Not required if ambient air purge incorporated in vss setup.

3 Additional GC runs may be performed to obtain organic data and to assure cleanliness of the system at the discretion of the sampling scientist and sha!l be identified in the deliverable report. Organic data obtained from the on-line GC is developmental. 
HHC-SD-WM-TP-299, REV O

\section{A2. 1.3 Radiation Screening and Sample Transport}

All vapor samples shall be stored under chain-of-custody requirements by SML while performing a radiological survey of certain items used during sampling. Surveys are conducted to assure compliance with Department of Transportation (DOT) shipping regulations and offsite laboratory acceptance criteria. Items surveyed include four HEPA filters and one tritium trap and are analyzed following procedures specified in Table A-4 (Bratzel 1994).

The results from the radiation screening are submitted to and shall be evaluated by Sampling and Mobile Laboratories (SML) to ensure the samples meet the analytical criteria specified in Table A-3. SML shall provide a Format II report to each analytical laboratory to specify survey results (refer to Section A6.2).

Trip blanks and field blanks are to accompany the waste samples to the laboratory. For specific information concerning sample and blank handling, custody, and transport refer to quality assurance/quality control requirements in Section A3.1.

Table A-3. Limits For Acceptable Radionucl ide Activity Levels.

\begin{tabular}{|l|c|c|c|c|}
\hline \multicolumn{1}{|c|}{ Organization } & Total $\alpha$ & Total $B / \gamma$ & Total $\alpha / B / \gamma$ & Units \\
\hline $\begin{array}{l}\text { PNL Analytical } \\
\text { Chemistry Laboratory }\end{array}$ & $\leq 100$ & $\leq 400$ & N/A & $\mathrm{pCi} / \mathrm{g}$ \\
\hline $\begin{array}{l}\text { Oak Ridge National } \\
\text { Laboratory }\end{array}$ & $\leq 135$ & $\leq 450$ & $\mathrm{~N} / \mathrm{A}$ & $\mathrm{pCi} / \mathrm{g}$ \\
\hline WHC-CM-2-14 & $\mathrm{N} / \mathrm{A}$ & $\mathrm{N} / \mathrm{A}$ & $\leq 2000$ & $\mathrm{pCi} / \mathrm{g}$ \\
\hline
\end{tabular}




\section{A2.2 LABORATORY ANALYSIS}

The responsibilities of the analytical laboratories to this sampling event are given in this section. Additional quality control and deliverable requirements are given in Sections $A 3.0$ and $A 6.0$.

\section{A2.2.1 Preparation of Sample Media Containers}

The laboratory performing the contracted analytical work shall supply labeled sample containers (SUMMA canisters and selective sorbent media) to SML at least 48 hours in advance of the scheduled sampling date. Each sample media container shall be certified as clean and prepared according to procedures called out in Table $\mathrm{A}-1$.

\section{A2.2.2 Sample Analysis}

Sample material retrieved from the tank TY-101 vapor space and contained within the SUMMAO canisters shall be analyzed for organic compounds following modified EPA procedure TO-14 and for permanent gases $\mathrm{CO}_{2}, \mathrm{CO}, \mathrm{CH}_{4}, \mathrm{H}_{2}$, and $\mathrm{N}_{2} \mathrm{O}$ using gas chromatography. The sorbent traps contain analyte-specific sorbent media and shall be analyzed for these specific analytes. The triple sorbent traps contain sorbent media designed to allow a broad range of organic species to be retained. Table $A-4$ identifies the appropriate laboratory procedures used in each analysis.

One SUMMA Canister shal1 be archived at the PNL Laboratory following receipt and control procedure PNL-TVP-07 for six months or until instructed by the Tank Vapor Program to clean the canister for reuse. If necessary, requirements for further quantification and speciation shall be conveyed through a Letter of Instruction by the Characterization Program and/or revision to this Tank Characterization Plan.

Any analyses prescribed by this document, but not performed, or other deviations, shall be identified and include justification in the appropriate data report.

\section{A2.2.3 Insufficient Samples}

Unlike a solid sample which may have full or partial recovery, vapor sample media contain either good, bad, or no sample. A sample that is bad or empty may not have a proper seal. Partial recovery of a vapor sample is not an issue, however, the number of good samples may be an issue. All good samples, except the SUMMA canister archive, shall be analyzed. If there are insufficient good samples to perform all requested analyses, the Characterization Program Office and the Tank Vapor Issue Resolution Program shall be notified. The SUMMA ${ }^{\circledR}$ canister archive shall be used if one or more of the SUMMA ${ }^{\Theta}$ canister samples is compromised. 


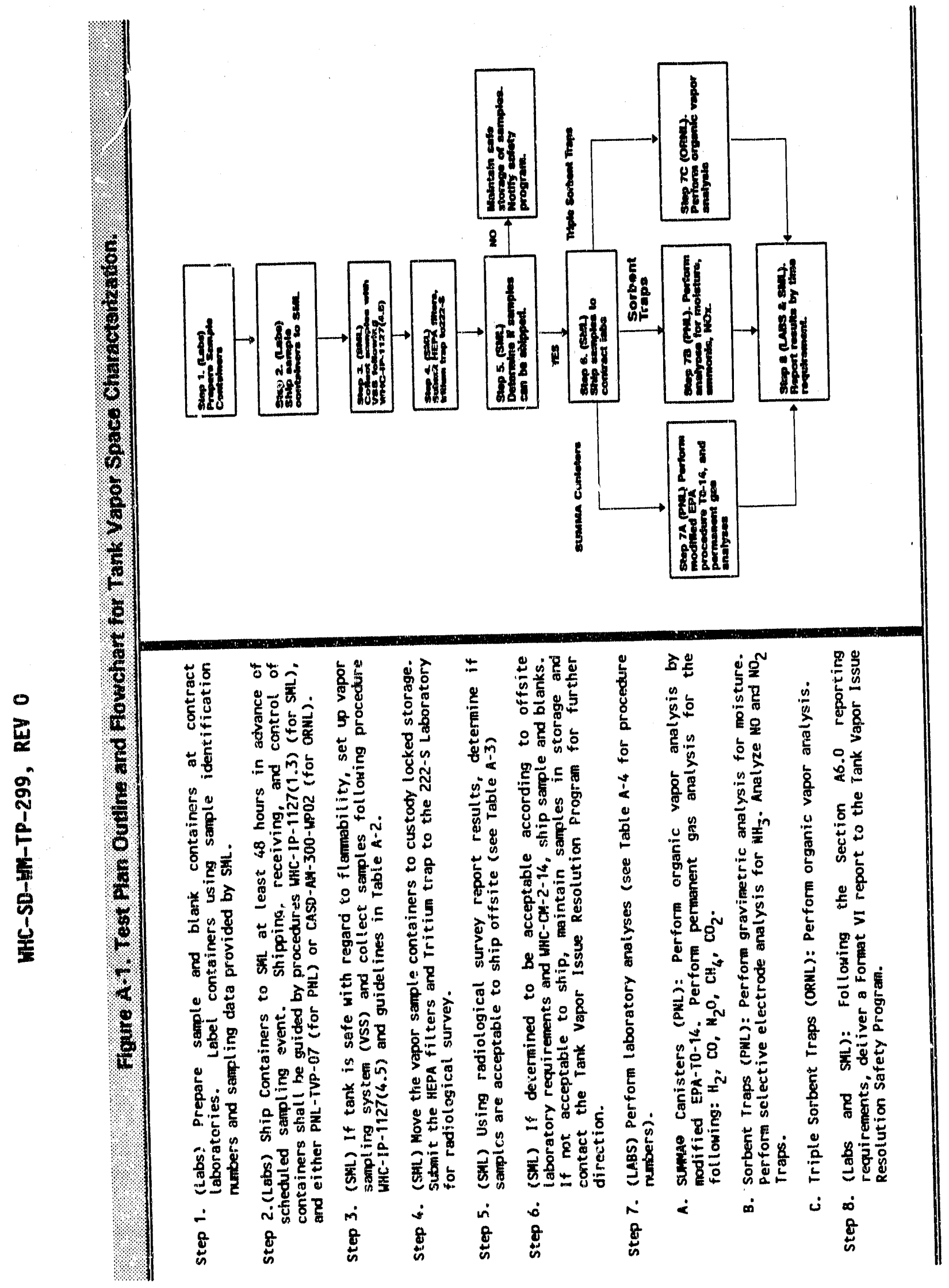

0
1 


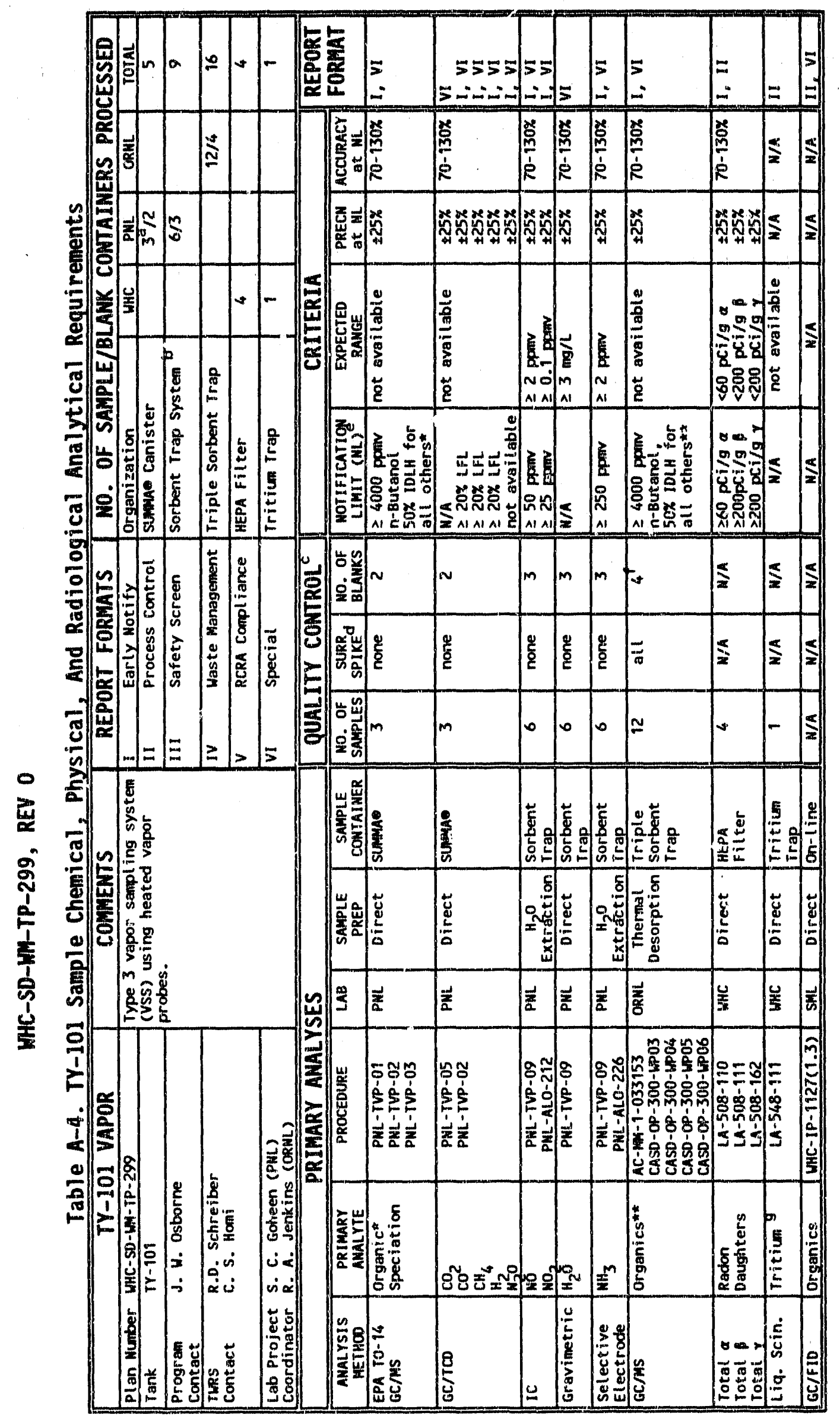

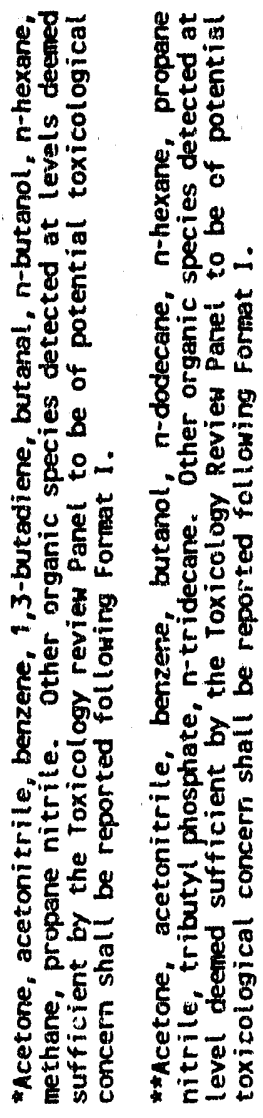

$\frac{1}{2}$

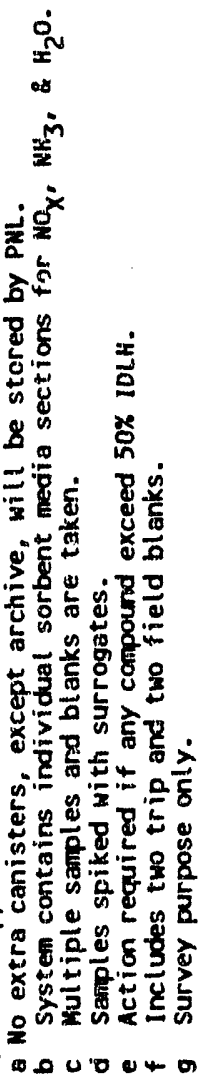




\section{A3.0 QUALITY ASSURANCE \& QUALITY CONTROL}

This Tank Characterization Plan and analytical laboratory operations are approved by the WHC Environmental Safety, Health, and Quality Assurance (ESH\&QA) Program provided the following conditions are met.

1) Each laboratory has a quality assurance program that meets the applicable requirements of DOE order $5700.6 C$, or United States 10 CFR 830.120 . In addition, it must also meet the requirements of QAPP-013 (Keller 1994) and when implemented in August 1995, the Hanford Analytical Services Quality Assurance Plan (DOE 1994).

2) Each analysis and media preparation procedure given in Tables $A-1$ and A-4 are documented by the laboratory and available to ESH\&QA.

3) Any modifications made to, or deviations from, the prescribed procedures are documented in controlled notebooks and justified in the deliverable report.

The PNL tank vapor program is governed by a QA Plan (Barnes 1995). ESH\&QA will qualify laboratories for continued use by the TWRS Characterization Program after receipt of a $Q A$ PIan, followed by an audit and corrective action phase.

\section{A3.1 Sampling Operations}

SML shall provide unique sample label and identification numbers to the laboratories. Each sample identification number shall have the following format:

\section{SXXXXX-WYY-LLL, where:}

$X X X X=$ unique number assigned to the sampling event,

$W=a$ letter code indicating the day of a multi-day sampling event,

YY = a 2-digit sample code found in Table A-2, List of Sample and Activities, column one.

$L L L=$ a special lab assigned code.

Once the sample collection media has been received by SML from the laboratory, it shall remain in the physical control of the custodian, locked in a secure area, or prepared for shipping with tamper evident tape under conditions specified on the chain-of-custody form and in accordance with laboratory operating procedure WHC-IP-1127(1.3) "Chain-of-Custody for RCRA and CERCLA Protocol Samples".

Applicable operating procedures for the tank TY-101 vapor space sampling activities are contained in work package WS-95-00018. Vapor samples, trip blanks, and field bianks are to be collected in accordance with Tables A-1 and $A-2$ and laboratory operating procedure WHC-IP-1127(4.5) "Collection of SUMMAO Canisters \& Sorbent Tube Samples Using the Vapor Sampling System (VSS)" and shipped to the laboratory in accordance with Hazardous Material Packaging and Shipping, WHC-CM-2-14.

All sampling activities shall be documented in controlled field logbooks maintained by sampling personnel (SML) and shall contain, but are not limited to: 
WHC-SD-WM-TP-299, REV 0

1) identification of tank and riser number and photographs of the sample location in which the sampling is conducted,

2) if any anomalies are observed, corresponding sample identification numbers, flow rates, pressures, temperatures, and other operational parameters affecting the sample,

3) any conditions that the sampler may observe during the sampling event ( $i$. e., odors, nearby machinery in operation, etc.),

4) names and titles of personnel involved in the field activity and their responsibilities,

5) instrument calibration dates.

SML is responsible for documenting any problems and procedural changes affecting the validity of the sample in a controlled field notebook and shall enter this information in the comment section of the chain-of-custody form for addition to the data reports.

\section{A3.2 Laboratory Operations}

The SUMMA ${ }^{\oplus}$ canisters and Sorbent Trap Systems shall be prepared, certified, and labeled by the performing laboratories following the laboratory quality control procedures identified in Table A-1. The laboratory supplying the sample collection media shall initiate the chain-of-custody in accordance with the laboratory operating procedure WHC-.IP-1127(1.3), "Chain-of-Custody for RCRA and CERCLA Protocol Samples" using sample label and identification numbers provided by SML.

Thie sample receipt and control procedure used in the PNL laboratory is PNLTVP-07. Oak Ridge National Laboratory shipping and receiving is done by procedure CASD-OP-300-WPO2. Analyses shall be performed following the proredures in Table A-4.

Method specific quality control such as calibrations and blanks are also found in the analytical procedures. Sampla quality control (duplicates, spikes, standards) specified in the applicable DQO's are identified in Table A-4. Due to the developmental work being done with the analysis procedures and potential sample differences (between tanks), changes in procedures may be needed. 


\section{HHC-SD-HM-TP-299, REV 0}

\section{A4.0 ORGANIZATION}

The organization and responsibility of key personnel involved in this tank TY-101 vapor sampling project are listed in Table A-5.

Table A-5: Tank TY-101 Project Key Personnei List

\begin{tabular}{|c|c|c|}
\hline Individual (s) & Organization & Responsibi?!ty \\
\hline S. C. Goheen & Pacific Northwest Laboratory & $\begin{array}{l}\text { Project Manager for Vapor } \\
\text { Sample Characterization }\end{array}$ \\
\hline R. A. Jenkins & Oak Ridge National Laboratory & $\begin{array}{l}\text { Project Manager for Vapor } \\
\text { Sample Characterization }\end{array}$ \\
\hline J. G. Kristofzski & WHC 222-S Laboratory & $\begin{array}{l}\text { Project Manager for Sample } \\
\text { Radiological Survey } \\
\end{array}$ \\
\hline R. D. Schreiber & TWRS Characterization Support & $\begin{array}{l}\text { TY-101 Tank Characterization } \\
\text { Plan Engineer }\end{array}$ \\
\hline J. W. Osborne & $\begin{array}{c}\text { TWRS Tank Vapor Issue } \\
\text { Resolution Program }\end{array}$ & $\begin{array}{c}\text { Vapor Issue Resolution } \\
\text { Program Manager }\end{array}$ \\
\hline H. Babad & TWRS Characterization Program & $\begin{array}{l}\text { Tank Safety Screening } \\
\text { Scient.st }\end{array}$ \\
\hline R. S. Viswanath & Special Analytical Studies & $\begin{array}{l}\text { Special Analytical Studies } \\
\text { Vapor Program Technical Lead }\end{array}$ \\
\hline R. D. Mahon & $\begin{array}{c}\text { Sampling and Mobile } \\
\text { Laboratories }\end{array}$ & $\begin{array}{c}\text { Sampling and Mobile } \\
\text { Laboratories Vapor Sampling } \\
\text { Program Lead }\end{array}$ \\
\hline E. H. Neilsen & Waste Tank Safety Engineering & $\begin{array}{l}\text { Vapor Sampling } \\
\text { Cognizant Engineer }\end{array}$ \\
\hline D. R. Carls & $\begin{array}{c}\text { Industrial Hygiene and Safety } \\
\text { Program }\end{array}$ & $\begin{array}{l}\text { Industrial Hygiene Point of } \\
\text { Contact if Notification Limit } \\
\text { is Exceeded (FAX 372-3522) }\end{array}$ \\
\hline $\begin{array}{l}\text { West Area Shift } \\
\text { Operations } \\
\text { Manager }\end{array}$ & Tank Farm Operations & $\begin{array}{c}\text { West Tank Farm Point of } \\
\text { Contact if Notification Limit } \\
\text { is Exceeded (373-3475) }\end{array}$ \\
\hline
\end{tabular}

\section{A5.0 EXCEPTIONS, CLARIFICATIONS, AND ASSUMPTIONS}

\section{Toxicology Review Panel}

The Toxicology Review Panel (TRP) is a group of toxicologists, industrial hygienists, and occupational medicine physicians that convene to review quantitative vapor sample data, identify compounds of toxicological concern, and make recommendations to the WhiC Tank Vapor Program Manager regarding potential impacts to worker health and safety. 


\section{Toxicological Concern}

From a list of 160 arialytes found in tank C-103, the TRP identified 19 ana?ytes of toxicological interest. These analytes and others may be identified during TRP review of qualitative GC vapor data as being of toxicological concern if they exceed recommended ievels inside the tank headspace. Established guidelines on these analytes are base on Consensus Exposure Standards (CES).

\section{Consensus Exposure Standards}

A CES is generally defined as the most stringent of known regulatory or recommended toxicological values for the occupational setiting including the threshold limit value (TLV), pernissible exposure limit (PEL), recommended exposure limit (REL), and biological exposure limit (BEL). For those constituents with unknown toxicological values, the TRP will be responsible for development of a CES.

\section{Trip 31 anks and Field Blanks}

Trip Blanks are sampling devices prepared and handled in the same manner as samples, except that they are never opened in the field. Field Blanks are sampling devices prepared and handled in the same manner as the samples, but no tank gases are drawn through them. Laboratories supplying blanks may opt to analyze only one trip blonk unless it is determined to be contaminated, in which case all trip blanks are to be analyzed.

\section{Sample Custodian}

The sample cusiodian is the designated SML cognizant scientist or assisting scientific technician, lead sampler, or laboratory scientist or tecinician who signs the received by block on the chain-of-custody. Transfer of custodianship occurs when the custodian signs the relinquished by block on the chain-of-custody and releases the sample(s) to the new custodian signator.

\section{Physical Control}

Physical control of a sample inciudes being in the sight of the custodian, in a room which shall signal an alarm when entered, or locked in a cabinet.

\section{A6. 0 DELIYERABLES}

The Pacific Northwest Laboratory, Oak Ridge National Laboratory, and Sampling and Mobile Laboratories VSS sampiing and analyses of tank TY-101 vapors shall be reported as Format VI (Section A6.3). In addition, the analytical laboratories shail receive forinat II reports from Sampling and Mobile Laboratories as described in Section A6.2. Any analyte exceeding the notification limit prescribed in Table A-4 shall be reported as Format I (Section A6.1). Other organic species detected at levels deemed sufficient by the TRP to be of potential toxicological concern shall also be reported following Format I. Additional information regarding reporting formats is given in Schreiber (1994a, $1994 b, 1994 \mathrm{C}$ ). 


\section{A6.1 FORMAT I REPORTING}

Table A-4 contains the notification limits for specific analytes. Analytes that exceed notification limits defined in the DQO processes shall be reported by the Project Maniiger, delegate, or Health Physics Management by calling the West Area Shift Manager of Tank Farm Operations at 373-3475 immediately. This verbal communication must be followed within 3 working days by written communication to the Tank Vapor Issue Resolution Program, the Industrial Hygiene and Safety Program, and the Characterization Prcjram, documenting the observation(s). A further review of the data, including quality control results and additional analyses for verification of the exceeded analyte, may be contracted between the performing laboratory and the contacts above.

\section{A6.2 FORMAT II REPORTIMG}

Results of the 222-S Lahoratory's radiological survey shall be reported by Sampling and Mobile Laboratories as Format II to the vapor analytical laboratories listing the picocuries per sample ( $\mathrm{CCi} / \mathrm{sample)}$ for each sample submitted for analysis. This Format II report should also provide the sample collection sequence and volumes, verification of trip and field blank use, and any aromalous sampling conditions to accompany, if possible, the shipment of samples. Alternatively, this sampling report may be transmitted by FAX to the analytical laboratories within 48 hours after the samples have been shipped.

\section{A6.3 FORMAT VI REPORTING}

All Format VI reports shall be delivered to the Tank Vapor Safety Resolution Program, R. S. Viswaneth of Special Analytical Studies, the Characterization Program office, Analytical Services, and the Tank Characterization Resource Center.

Each analytical laboratory and SML shall deliver three reports. Sampling and analytical data are requested within 5 weeks after receipt of both the samples and supporting data and shall consist of, at a minimum, data tables reporting sample collection data, industrial hygiene tank monitoring data, an radiation screening results obtained by SML, or the results of each anaiysis performed by the analytical laboratories. A final report shall be delivered within a nine week period after receipt of both the samples and supporting data. A cleared final report shall be delivered after it has completed the proper clearance. Final reports shall be submitted to clearance in parallel to being submitted to the WHC customers identified above.

The final sampling report from Sampling and Mobile Laboratories shall be a WHC supporting document, with sponsor-limited release. It should include:

1) a description of sampling equipment used;

2) a description of sampling quality controls applied (e.g., leak and cleanliness tests of the sampling manifold, system temperature and pressure monitoring/alarms, instrument calibration details);

3) sampling event chronology and sample collection schedule (complete list of samples, by ID\#, time collected, flow rates, etc.);

4) any industrial hygiene tank monitoring data collected before or during sampling event;

5) an evaluation of sources of sampling errors; 
6) sample radiation screening results;

7) sample storage and shipment details; and

8) copies of all chain-of-custody forms.

The cleared final report from the analytical laboratories shall be acceptable for distribution to the pubiic. To the extent possible, the final reports sinould include:

1) A summary of analytical results;

2) a description of sample device preparation (and manufacture if appropriate), citing procedures and logbooks used;

3) references providing traceability of sample device cleanliness;

4) a brief description of analytical methods, with procedures cited;

5) a brief explanation of how analytical systems control was demonstrably maintained;

6) a brief description of sample storage and shipment conditions, citing procedures and logbooks used;

7) a listing of analytes of quantitation (target analytes), with analytical method detection limit, range for which instrumentation is calibrated, number of calibration points used, and statistical data on linearity of calibration;

8) quantitative analytical results, expressed as dimensionless (ppmv or ppbv) concentration, and mass concentration $\left(\mu \mathrm{g} / \mathrm{m}^{3}, \mathrm{mg} / \mathrm{L}\right.$, etc., calculated at $0{ }^{\circ} \mathrm{C}$ and 1 atmi) of target analytes (identified by name and Chemical Abstract Service number) in each tank air sample;

9) tentative identification and semi-quantitative analytical results, expressed in both mass and dimensionless concentrations (if possible) of non-target organic analytes (identified by name and Chemical Abstract Service number) in each organic vapor sample;

10) a statistical summary (i.e., mean, standard deviation) for multiple analyses and/or multiple samples for all analytes (positively and tentatively identified compounds) in both mass and dimensionless concentrations (if possible);

11) a summary of all exceptional conditions, such as deviations from procedure or protocol, results obtained olitside of instrument calibration range, sorbant trap breakthroligh of analytes, or poor surrogate recoveries; and

12) copies of all chain-of-custody forms.

\section{A7.0 CHANGE CONTROL}

Under certain circumstances, it may become necessary for the performing laboratory to make decisions concerning a sample without review of the data by the customer or the Characterization Program. These changes shall be brought to the attention of the project manager and the Characterization Program as quickly as possible and documented accordingly. Changes must be justified in their documentation and follow the protocols defined in the Quality Assurance Manual, WHC-CM-4-2, Section QR 3.0, Design Control and in Standard Engineering Practices, WHC-CM-6-2, Section EP-2.2, Engineering Document Change Control Requirements. All changes shall also be clearly documented in the final data package.

Additional analysis of sample material from this vapor space characterization project at the request of the Characterization Program shall be performed according to a revision of this Tank Characterization Plan. 


\section{WHC-SD-WM-TP-299, REV 0}

\section{A8.0 REFERENCES}

Barnes, B. 0., 1995, Quality Assurance Plan for PNL TWRS Tank Vapor Program, MCS-

046 Rev. 0, Pacific Northwest Laboratory, Richland, Washington.

Bellus, T. H., 1993, Configuration of Hewlett Packard (HP) 5890 Series II Gas Chromatograph (GC) for DML1, (internal memo 12240-SAA93-039 to L. L. Lockrem, July 10), Westinghouse Hanford Company, Richland, Washington.

Bratze1, D. R., 1994, Letter or Instruction for Radiological Analyses to Support Fiscal Year 1995 Tank Vapor Sampling, (internal memo 74310-94-32 to J. G. Kristofzski, November 30), Westinghouse Hanford Company, Richland, Washington.

Haller, C. S., 1995, Fiscal Year 1995 Tank Waste Remediation System Tank Waste Analysis Plan, WHC-SD-WM-PNL-091, Rev. 0, Westinghouse Hanford Company, Richland, Washington.

Keller, K. K., 1994, Quality Assurance Project Plan for Tank Vapor Characterization, WHC-SD-WM-QAPP-013, Rev. 2, Westinghouse Hanford Company, Richland, Washington.

Osborne, J. W., J. L. Huckaby, E. R. Hewitt, C. M. Anderson, D. D. Mahlum, B. A. Pulsipher, J. Y. Young, 1994, Data Quality Objectives for Generic In-Tank Health and Safety Vapor Issue Resolution, WHC-SD-WM-DQ0-002, Rev. 0 , Westinghouse Hanford Company, Richland, Washington.

Price, D. N., 1994, Rotary Core Vapor Sampling Data Quality Objective, WHC-SD-WM$\mathrm{SP}-003$, Rev. 0, Westinghouse Hanford Company, Richland, Washington.

Schreiber, R. D., 1994a, Format I Reporting Requirement, (internal memo 7E720-94121 to J. G. Kristofzski, August 15), Westinghouse Hanford Company, Richland, Washington.

Schreiber, R. D., 1994b, Revised Interim Tank Characterization Plan Guidance, (letter 7E720-94-121 to C. S. Haller, May 13), Westinghouse Hanford Company, Richland, Washington.

Schreiber, R. D., 1994c, Point of Contact/Distribution List, (internal memo 7E720-94-141 to J. G. Kristofzski, October 11), Westinghouse Hanford Company, Richland, Washington.

United States Department of Energy Order 5700.6C, of 08-21-91, Quality Assurance.

United States Code of Federal Regulations, 10 CFR, Part 830, Nuclear Safety Management; Section 120, Quaiity Assurance Requirements. 

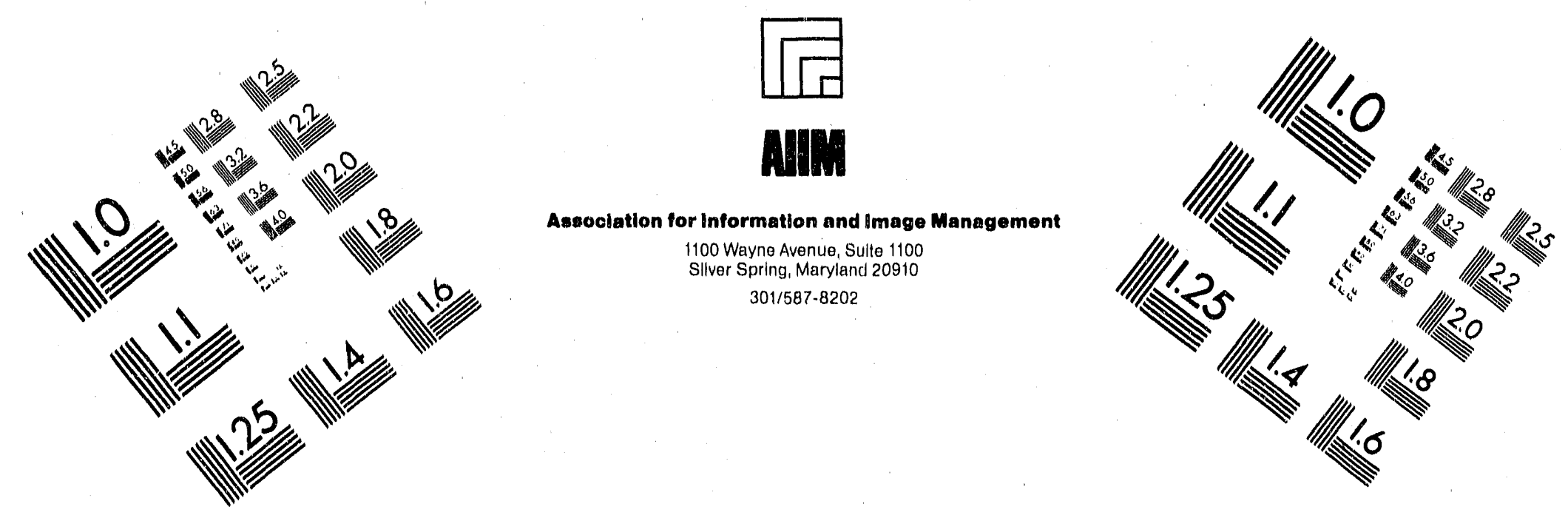

\section{Centimeter}

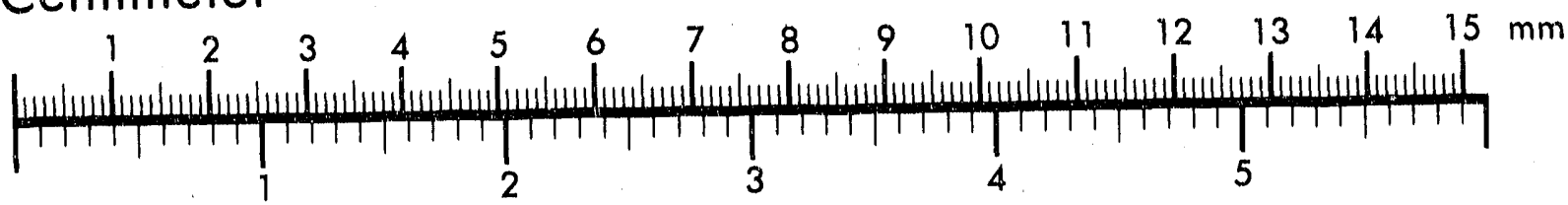

Inches
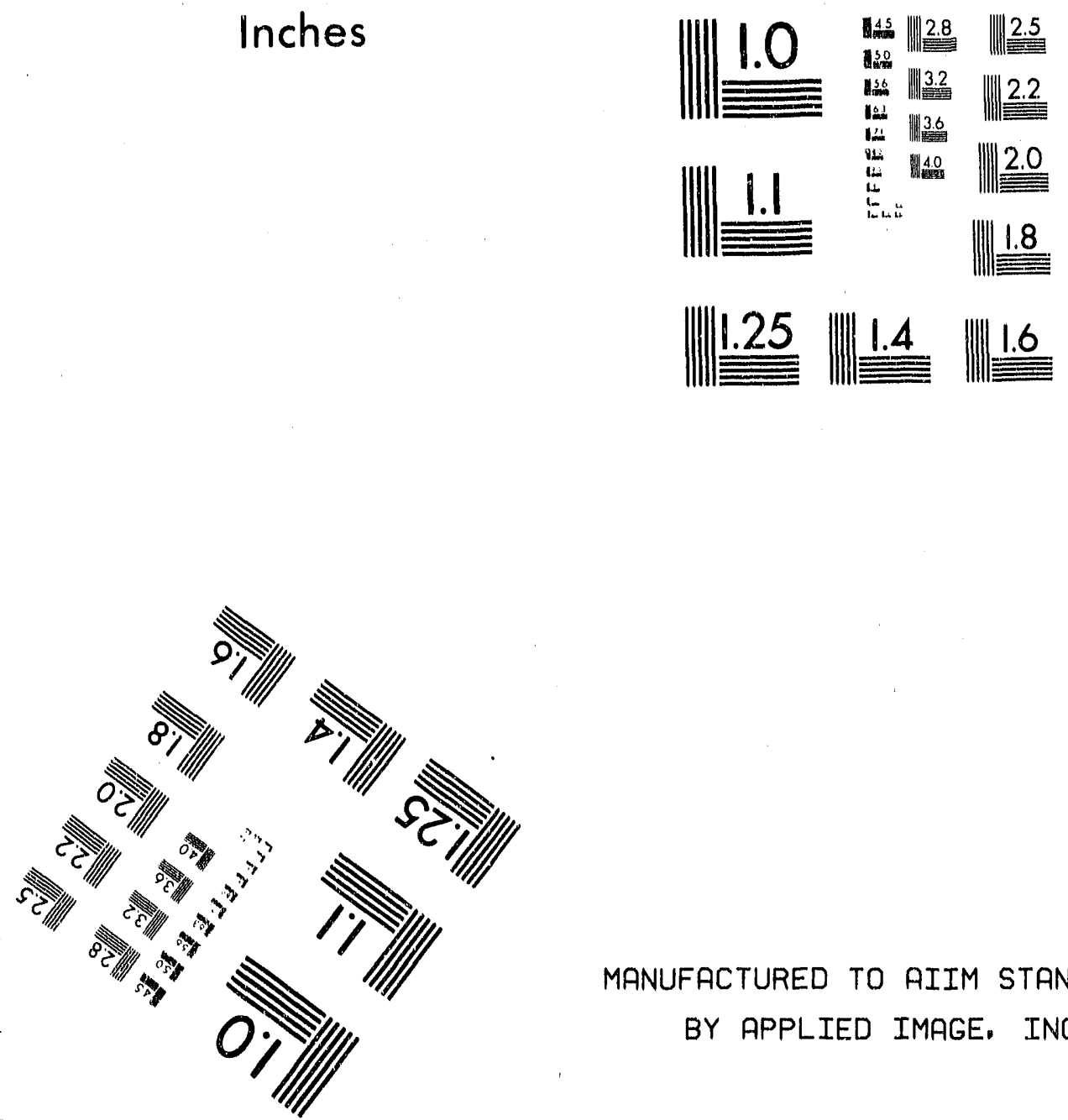

MANUFACTURED TO AIIM STANDARDS

BY APPLIED IMAGE, INC.

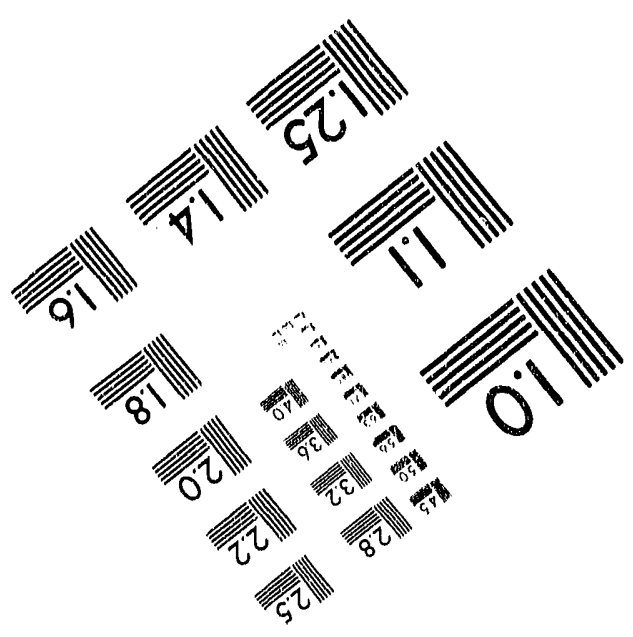




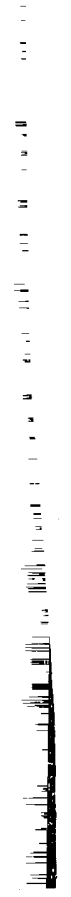



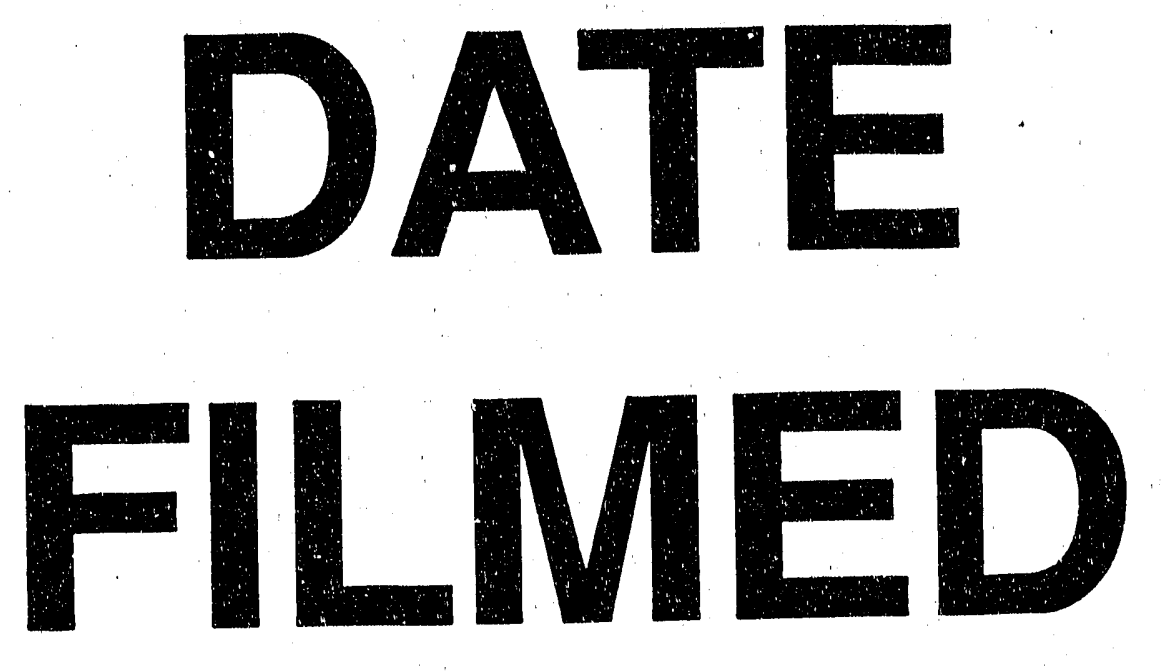

$6 / 14 / 95$
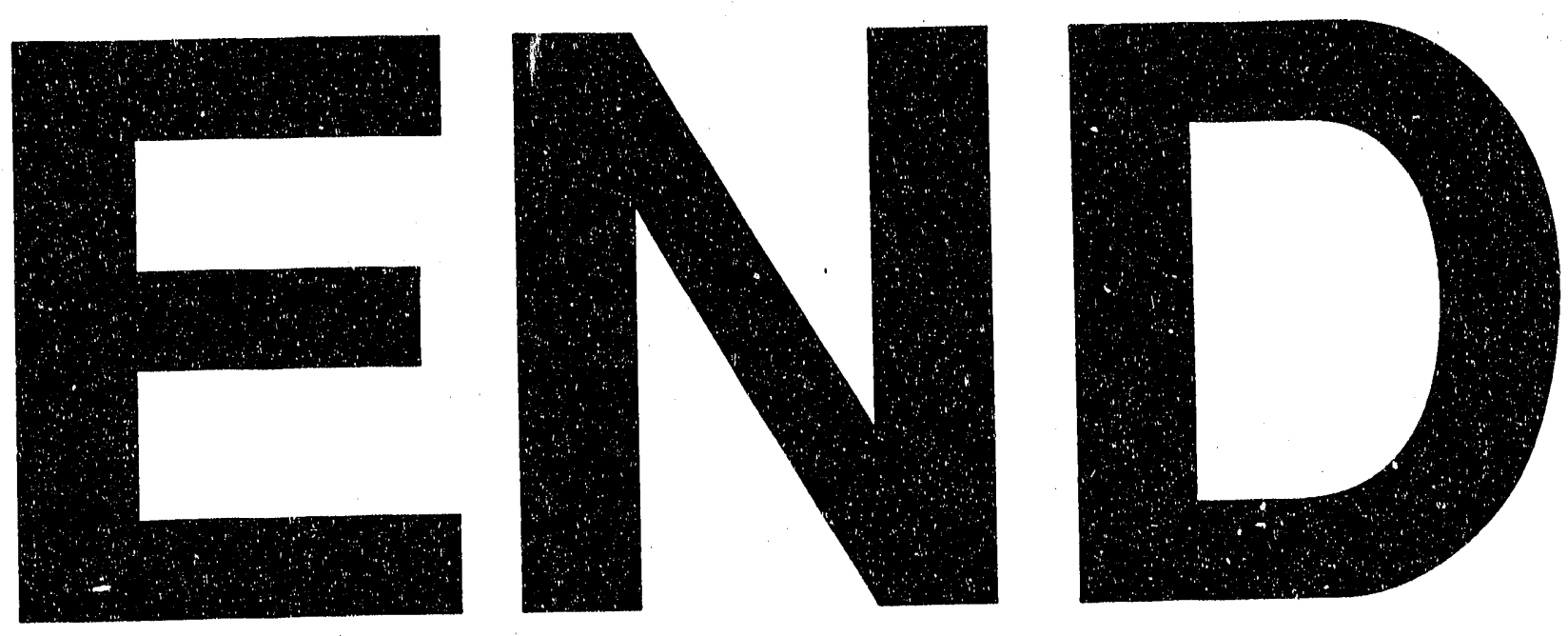